\title{
Application of stochastic programming to electricity generation planning in South Africa
}

\author{
M Bashe* \\ M Shuma-Iwisi ${ }^{\dagger}$ \\ MA van $\mathrm{Wyk}^{\ddagger}$ \\ Received: 9 May 2019; Revised: 7 October 2019; Accepted: 13 November 2019
}

\begin{abstract}
A two-stage stochastic programming model is used to solve the electricity generation planning problem in South Africa for the period 2013 to 2050, in an attempt to minimise expected cost. Costs considered are capital and running costs. Unknown future electricity demand is the source of uncertainty represented by four scenarios with equal probabilities. The results show that the main contributors for new capacity are coal, wind, hydro and gas/diesel. The minimum costs obtained by solving the two-stage stochastic programming models range from R2 201 billion to R3 094 billion.
\end{abstract}

Key words: Two-stage stochastic programming, planning, electricity generation, scenario, expected cost, capacity.

\section{Introduction}

According to Sen \& Zhou [34] stochastic programming (SP) deals with a class of optimisation models and algorithms in which some of the data may be subjected to significant uncertainty. The authors suggest that SP models are appropriate when data evolves over time and decisions need to be made prior to observing the entire data stream. This is also the case in this work since electricity generation expansion plans are made in advance and amidst uncertain future electricity demand. The approach followed in this paper is based on SP, which was introduced by Dantzig [9].

In this paper, a two-stage stochastic programming (TSSP) model for electricity generation expansion planning in South Africa, is proposed. Advantages of adopting SP are discussed

\footnotetext{
${ }^{*}$ Corresponding author: School of Electrical and Information Engineering, University of Witwatersrand, South Africa, fax: 021 8082409, email: mbashe@mweb.co.za

${ }^{\dagger}$ School of Electrical and Information Engineering, University of Witwatersrand, South Africa, fax: 021 8082409, email: mercy.shuma-iwisi@wits.ac.za

${ }^{\ddagger}$ School of Electrical and Information Engineering, University of Witwatersrand, South Africa, fax: 021 8082409, email: anton.vanwyk@wits.ac.za
} 
by Higle [22] and Bisschop [6], and a general form of a linear TSSP problem is given by Shapiro et al. [32] as seen in equations (1) to (4):

$$
\begin{aligned}
\min & c^{T} x+E_{\xi}\left[q^{T}(\omega) y(\omega)\right] \\
\text { s.t. } \quad T(\omega) x+W(\omega) y(\omega) & =h(\omega), \\
x, y(\omega) & \geq 0 .
\end{aligned}
$$

Where:

- $x$ is a decision vector whose values are to be calculated in stage one;

- $c, A$, and $b$ are known matrices corresponding to $x$, with sizes $n_{1} \times 1, m_{1} \times n_{1}$ and $m_{1} \times 1$, respectively;

- $\xi=\xi(\omega)$ which emphasises that $\xi$ is a random vector;

- $y(\omega)$ is the second stage decision variable whose values are to be calculated in stage two;

- $W(\omega), q(\omega), h(\omega)$ and $T(\omega)$ are matrices corresponding to $y(\omega)$ with sizes $m_{2} \times n_{2}$, $n_{2} \times 1, m_{2} \times 1$ and $m_{2} \times n_{1}$, respectively. For a given realisation of $\omega$, the matrices $q(\omega), h(\omega)$ and $T(\omega)$ become known;

- $\xi^{T}(\omega)=\left(q^{T}(\omega), h^{T}(\omega), T_{1}(\omega), \cdots, T_{m_{2}}(\omega)\right)$; and

- $E_{\xi}$ represents the mathematical expectation with respect to $\xi$.

In this work, stage one of the proposed TSSP model determines the investment costs for new capacity that will meet unknown future electricity demand. Stage two allocates available capacity to the future electricity demand. The objective is to minimise investment costs with uncertainty in future electricity demand. TSSP is adopted because the methodology:

- is appropriate when electricity demand unfolds over time and decisions need to be made prior to knowing what the entire electricity demand will be, and

- differentiates between what is known and what remains uncertain when decisions are made.

The paper is organised as follows, the application of SP in electricity generation planning is discussed in Section 2. A brief discussion about scenarios is provided in Section 3. The data used in the study is explained in Section 4 and the methodology followed is presented in Section 5. The results obtained are presented in Section 6 and the conclusion is in Section 7. Following the conclusion are Appendices A to J. Appendix A provides more details on existing capacity. Details for committed capacity are in Appendix B. Assumed capacity decommissioning schedules are in Appendices $\mathrm{C}$ to E. Input data for potential new technologies is in Appendices F to J.

\section{Stochastic programming in electricity generation capacity planning}

The WWF South Africa (WWFSA) [66] proposed an increase in renewable generation capacity into the South African system, from between $6 \%$ and $9 \%$ as suggested by [37], 
to between $11 \%$ and $19 \%$ by 2030 . The model used by WWFSA [66] was deterministic for system performance but probabilistic for cost analysis. The WWFSA results showed that the annual renewable energy production in the South African system can be as high as $25 \%$ in 2030, if the proposed increase is implemented. According to Birge \& Louveaux [5] one of the shortcomings of a deterministic model is that it can only use one scenario at a time. SP models have the capability of solving all the scenarios simultaneously and provide an optimal solution [5]. Hence, an SP model is used in this paper.

TSSP was used by Albornoz et al. [2] in Chile over a ten year planning horizon. Even though the Chile electricity industry is privately owned, it is regulated. The uncertainty considered by the authors was the future availability of the thermal power plants which were in operation. Albornoz et al. concluded that the TSSP results were realistic and of a better quality compared to the deterministic approach. The TSSP discussed in this paper is implemented in the South African electricity industry, which is largely state owned unlike the Chile case but also regulated.

Birge \& Louveaux [5] discussed multi stage SP models which was later reduced to two-stage programming models. Birge \& Louveaux's discussion was based on the TSSP model, where electricity demand and costs of various power plants to meet future electricity demand were sources of uncertainty. Bisschop [6] applied TSPP with the aim of determining new power plant design capacities that will meet an increased electricity demand. Bisschop's objective function was minimising daily costs consisting of a fraction of capital costs for building new design capacity, operating cost associated with the allocation decision, and the cost of importing electricity.

The model by Bisschop is similar to the Birge \& Louveaux [5] two-stage example, except that the total investment cost was not constrained to a budget and the existing capacity was considered, whereas Birge \& Louveaux did not do so.

In this work, TSSP is applied to the South African electricity generation expansion planning problem for the period 2013 to 2050. The objective was to determine new capacities that will meet electricity demand at minimum cost. The TSSP is implemented for a regulated electricity industry, where existing capacity was considered but without a budget constraint.

\section{Scenario analysis}

According to Milligan et al. [28] scenario analysis is the most common representation of uncertainty in stochastic power systems research and this is also the approach used in this study.

Lindgren \& Bandholding [27] defined scenario planning as a combination of scenario analysis and strategic planning. Amer et al. [1] used scenario, scenario planning and scenario analysis interchangeable. According to Schoemaker [33], "scenario planning stands out for its ability to capture a whole range of possibility in rich details", when compared to other managerial tools for strategic planning. According to Lindgren \& Bandholding [27] there is more than one definition of scenarios. However, these authors define scenarios 
as a vivid descriptions of a plausible future [27]. According to Lindgren \& Bandholding scenario planning is not a well defined field.

There is no optimal number of scenarios according to Ameer et al. [1], however the most recommended range is from 3 to 6 . The following four generic scenarios were defined by Zahradnickova \& Vacik [67]:

- Optimistic scenario

- Basic scenario

- Pessimistic scenario

- Realistic scenario

There are both qualitative and quantitative scenarios [27]. The Forest of Broceliande [44] website defined qualitative scenarios as possible futures in the form of narrative text or story lines. Quantitative scenarios provide tables and figures incorporating numerical data [44]. The scenarios used in this study are quantitative. Although there is no one scenario development technique, generic steps for scenario development is proposed, see [1] for detail.

According to the South African Department of Energy [38] the IRP in the South African context is the national electricity long term plan which directs the expansion of electricity supply over a given period. In the South African Integrated Resources Plan (IRP) 20102030 update report [37] (IRP2010 update), scenarios were defined as a particular set of assumptions and set of future circumstances, providing a mechanism to observe the outcomes from these circumstances. The demand scenarios used in this study were taken from the IRP2010 update and details about these scenarios are shown in Figure 1.

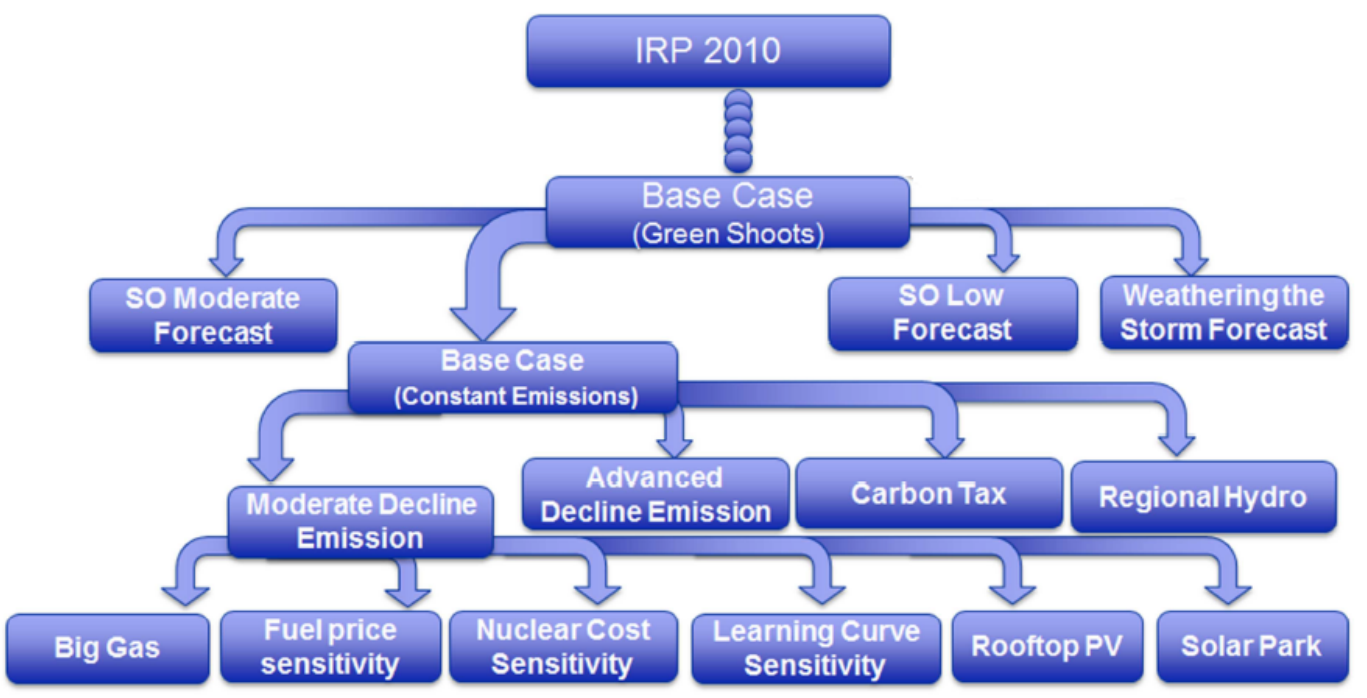

Figure 1: All scenarios considered in the IRP 2010-2013 report [37]. 


\section{Data}

The data used in this study was taken from the IRP2010 update report [37] since it contained demand scenarios which showed that there was uncertainty about the future demand. The IRP2010 update report also contained more detailed data about the potential technologies when compared to previously published IRP reports. The availability of this complete data made the application of the TSSP possible. The planning period used in the IRP2010 update report was 2013 to 2050, which was also used in this study. In the research work carried out the following data was used:

- The national electricity forecasted demand data. There were four demand scenarios and are presented in Figure 2 in Section 4.1.

- The national existing capacity which was meeting the demand in 2013. Details of this data are in Appendix A.

- The capacity that was committed by the minister of energy based on the IRP 20102030 (IRP2010) report [36] and the capacity committed by the public electricity utility in South Africa before the IRP2010 report. Details of this data are in Appendix B.

- A decommissioning schedule for the existing and committed capacity. Appendices $\mathrm{C}$ to E contain more details about this data.

- Potential technologies for meeting the forecasted demand together with the existing and committed capacity. The data used for the potential technologies is detailed in Appendices F to J.

\subsection{Data for demand scenarios}

The demand data was obtained from the IRP 2010-2030 update report [37]. The random variable, $\xi=S 1, S 2, S 3, S 4$ takes the values of the following demand scenarios with equal probability of $25 \%$ :

- Weathering the storm is represented by $\mathrm{S} 1$,

- System Operator (SO) Low Forecast by S2,

- Base Case Forecast by S3, and

- SO Moderate Forecast 4 by S4.

The demand data for the respective scenarios is displayed in Figure 2. The names given to the above scenarios are similar to the generic scenario names given by Zahradnickova \& Vacik [67] in Section 3. The only difference is on weathering the storm forecast and the realistic scenario. Other scenarios in Figure 1 were not considered because they were all based on the same demand scenario. The demand data for the respective scenarios are shown in Figure 2.

As it can be seen in Figure 2, S1 has the lowest demand forecast compared to other scenarios from the middle to the end of the investigation period. Similarly, S4 has the highest demand forecast compared to the other scenarios within the same period. The underlying reason for these differences was due to the economic outlook of each scenario which is shown in Table 1 . The actual South African average annual gross domestic 


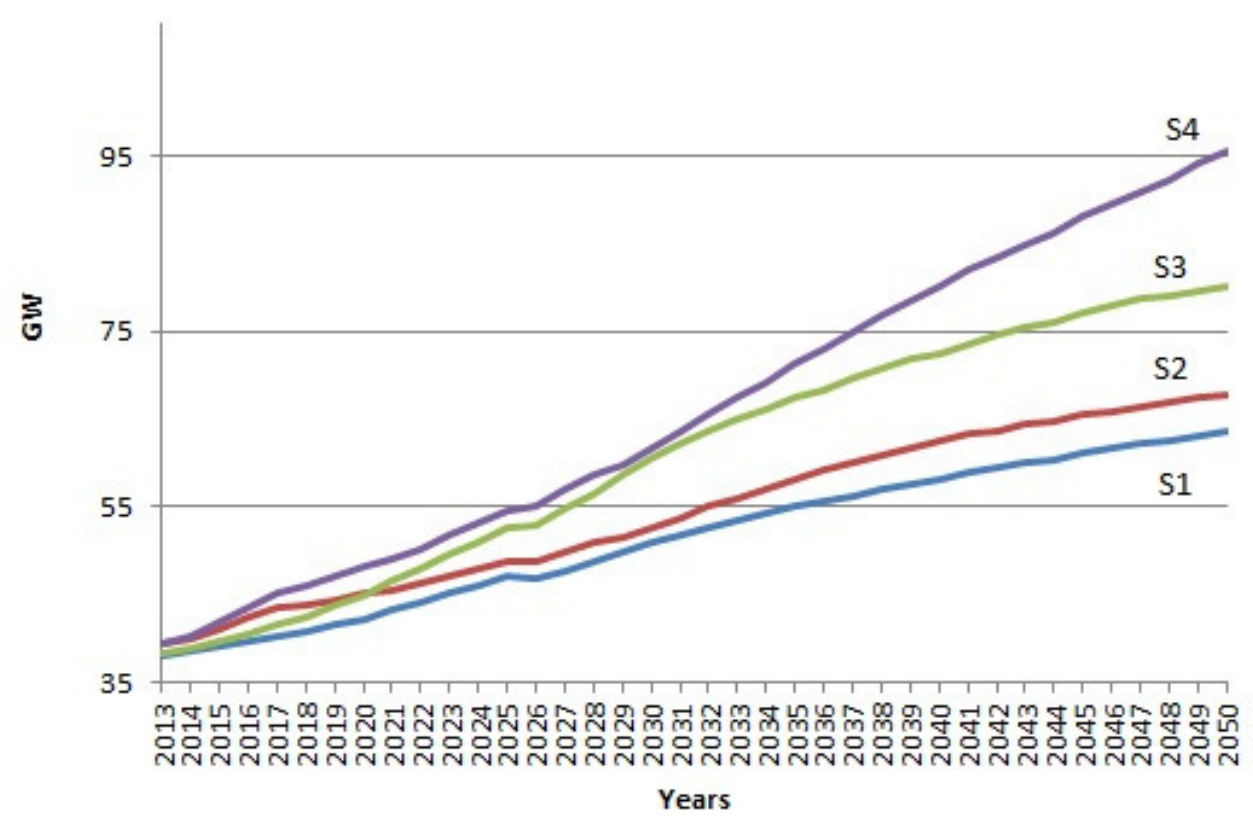

Figure 2: Demand scenarios whose data was obtained from [37].

\begin{tabular}{llll}
\hline Scenario & $\begin{array}{l}\text { Average annual } \\
\text { electricity demand } \\
\text { from 2013 to 2030 (\%) }\end{array}$ & $\begin{array}{l}\text { Average annual } \\
\text { electricity demand } \\
\text { from 2031 to 2050 (\%) }\end{array}$ & $\begin{array}{l}\text { Assumed average } \\
\text { annual GDP growth to } \\
\text { 2030 (\%) }\end{array}$ \\
\hline S1 & 1.8 & 1.3 & 5.4 \\
S2 & 1.9 & 1.5 & 5.4 \\
S3 & 2.7 & 1.9 & 4.5 \\
S4 & 2.8 & 2.4 & 2.9 \\
\hline
\end{tabular}

Table 1: Scenarios economic outlook [37].

product (GDP) growth rate from 2013 to 2018 was $1.4 \%$ [43]. This suggests that at the end of 2018 all the scenarios in Table 1 had an optimistic outlook because their assumed respective average annual GDP growth for this period ranged from $2.9 \%$ to $5.4 \%$, which is way above the real average annual GDP growth of $1.4 \%$.

\subsection{Data on existing and potential new capacity}

To meet the national electricity demand scenarios discussed in Section 4.1, both existing and potential new capacity were considered. Existing capacity included in this research consisted of Eskom fleet, non-Eskom fleet and committed power plants over the period, 2013 to 2050 (see appendices A and B). The sources of energy considered were coal, gas/diesel, hydro, nuclear, solar, wind, and other sources. 
The total existing capacity in 2013 was 48220 megawatt (MW) (see appendix A). During the investigation the existing capacity was increased by the capacity that was committed by the South African public electricity utility before IRP 2010 [36] and the committed capacity from the 2011 ministerial determinations [37]. The committed capacities are presented in Appendix B. The existing capacity was decreased by the capacity of power plants which were expected to be decommissioned during the investigation period. The actual assumed decommissioning dates and the corresponding capacities are in Appendices C to E. Appendices F to J give more details of the new potential technologies, their respective capacities and the corresponding costs.

The same fuel-based annual capacity factors are used throughout the investigation period for both existing and new power plants [42]. This is because the forecasted capacity factors are not available. The assumption made about constant capacity factors might over estimate and sometimes under estimate the actual energy per period produced by the model in Section 5.

Capacity factors for renewable sources were obtained from Calitz et al. [7], since this was the only local source with recent renewable capacity factors. Capacity factor data for other power plants was obtained from the South African public electricity utility. Due to the confidentiality nature of the utility's data, only the renewable sources' capacity factors are presented in Table 2 [7].

\begin{tabular}{lr}
\hline Energy source & Average capacity factor (\%) \\
\hline Solar photo voltaic (PV) & 26 \\
Wind & 35 \\
Concentrated solar power (CSP) & 31 \\
\hline
\end{tabular}

Table 2: Average capacity factor [7].

\section{$5 \quad$ Methodology}

The TSSP model discussed in this section follows from the discussion in Section 2. The TSSP model implemented here applies SP to the electricity capacity expansion planning problem in South Africa. The two-stage SP model minimises

- The total annual capital cost for new capacity in the first stage.

- The running costs for new capacity in the second stage. The running costs consist of fuel costs, fixed operating and maintenance (O\&M) costs, variable O\&M costs, and cost of unserved energy.

The total annual capital cost belongs to the first stage because the decision to expand capacity is taken at this stage. At the time of making this decision the demand growth or decline in the period under consideration is unknown. This is only realised in the second stage. The running costs are allocated to the second stage because they vary according to the energy produced to meet demand. 


\subsection{Mathematical model}

The following considerations were taken into account in the proposed model formulation:

- The objective function in this study minimises annual costs which spans over several years, 2013 to 2050.

- Both existing and new capacity are adjusted by capacity factors due to inefficiency of electricity generating technology.

- The existing capacity is not available throughout the entire planning horizon since some of it is decommissioned.

- The running costs are made up of fuel, fixed and variable maintenance, and the cost of unserved energy.

Equation (5) to equation (15) are only for new technologies. Equations for existing power plants are provided by equation (16) to equation (21), later in this section.

$$
\begin{aligned}
& \min \quad \sum_{t, p}\left[\operatorname{capc}_{p}^{t} x_{p}^{t}+E_{\xi} \boldsymbol{v}^{t}\right] \text {, } \\
& \text { s.t. } \\
& \sum_{k} \boldsymbol{y}_{p k}^{t} \leq e_{p}^{t} \operatorname{cap} f_{p}^{t} \quad \forall(t, p), \\
& \beta \boldsymbol{z}_{k}^{t}+\boldsymbol{d} \boldsymbol{u}_{k}^{t} \sum_{p} \boldsymbol{y}_{p k}^{t}=\boldsymbol{r}_{k}^{t} \quad \forall(t, k), \\
& \boldsymbol{r}_{k}^{t}=\left\{\begin{array}{l}
\left(\boldsymbol{d}_{k}^{t}\right) \boldsymbol{d} \boldsymbol{u}_{k}^{t} \text { if } k=1 \\
\left(\boldsymbol{d}_{k}^{t}-\boldsymbol{d}_{k-1}^{t}\right) \boldsymbol{d} \boldsymbol{u}_{k}^{t} \text { if } k=2
\end{array},\right. \\
& x_{p}^{t} \geq x_{p}^{t-1} \quad \forall(t, p), \\
& e_{p}^{t}=x_{p}^{t}-x_{p}^{t-1} \quad \forall(t, p), \\
& \sum_{k}\left(c u e^{t} \boldsymbol{z}_{k}^{t}+\boldsymbol{d} \boldsymbol{u}_{k}^{t} \sum_{p}\left(\operatorname{fom}_{p}^{t}+\operatorname{vom}_{p}^{t}+f_{p}^{t}\right) \boldsymbol{y}_{p k}^{t}\right)=\boldsymbol{v}^{t} \quad \forall(t), \\
& x_{p}^{t} \geq 0 \quad \forall(t, p), \\
& \boldsymbol{y}_{p k}^{t} \geq 0 \quad \forall(t, p, k) \text {, } \\
& \boldsymbol{v}^{t} \geq 0 \quad \forall(t), \\
& e_{p}^{t} \geq 0 \quad \forall(t, p),
\end{aligned}
$$

Where:

- Indices:

$-p$ is technology type.

$-k$ is demand category; base $(k=1)$ or peak $(k=2)$.

$-t$ is year, from $2013(t=1)$ to $2050(t=n)$.

- Parameters:

$-\beta$ is a binary parameter which is equal to 0 or 1 .

$-e_{p}^{t}$ is the existing capacity for technology $p$ at time $t$ [gigawatt $(\mathrm{GW})$ ]. 
- $\operatorname{capc}_{p}^{t}$ is annual capital cost for technology $p$ at time $t$ [Rand per kilowatt $(\mathrm{R} / \mathrm{kW})]$.

- $\operatorname{capf}_{p}^{t}$ is annual capacity factor for technology $p$ at time $t$.

- fom $_{p}^{t}$ is fixed operation and maintenance cost for technology $p$ at time $t[\mathrm{R} / \mathrm{kW}]$ per year.

- $v_{o m}^{t}$ is variable operation and maintenance cost for technology $p$ at time $t$ [Rand per megawatt hour (R/MWh)].

- $f_{p}^{t}$ is fuel cost of technology $p$ at time $t$ [Rand per gigajoule (R/GJ)].

- cue $e^{t}$ is the cost of unserved energy for all demand category at time $t[\mathrm{R} / \mathrm{kWh}]$.

- $\boldsymbol{d}_{k}^{t}$ is instantaneous electricity demand for $k$ at time $t$ GW.

$-\boldsymbol{d} \boldsymbol{u}_{k}^{t}$ is duration of demand for category $k$ and at time $t$; duration for base is 24 hours per day and 6 hours for peak.

$-\boldsymbol{r}_{k}^{t}$ is the required electricity for $k$ at time $t$ [gigawatt hour (GWh)].

- Variables:

$-x_{p}^{t}$ is new design capacity of technology $p$ at time $t[\mathrm{GW}]$. This decision was taken just before time $t$, for the capacity to be available at time $t$.

- cap $_{p}^{t}$ is based on fuel type [63]. Same capacity factor is used for all technologies and power plants that use the same fuel type. In this study the capacity factor based on fuel type is the quotient of all power plants that generated electricity using a particular fuel type in 2012 and the power plants availability capacity during the same period [63]. Power plant's available capacity is influenced by its planned and unplanned maintenance for each time $t$.

- $\boldsymbol{y}_{p k}^{t}$ is allocation of capacity to each demand, $k$ realization GW at time $t$ for technology $p$. This decision was taken at time $t$.

$-\boldsymbol{z}_{k}^{t}$ is the unserved capacity for $k$ at time $t[\mathrm{GW}]$. This decision was taken at time $t$.

- $\boldsymbol{v}^{t}$ is the total cost of: unserved cost of unserved energy, fuel, fixed and variable maintenance.

$\beta$ is equal to 1 when the available capacity is unable to meet electricity demand and equal to 0 when the capacity is able to meet demand. The variables in bold, in this section, are those that depend on the random variable $\xi=S 1, S 2, S 3, S 4$. Equation (5) is the objective function which minimises the capital cost for new capacity and operational costs. The running costs $\boldsymbol{v}^{t}$ as defined at the beginning of section 5 are expanded in equation (11). The constraint in equation (6) ensures that allocated capacity is less than the available capacity in year $t$, which is the installed capacity multiplied by the capacity factor. Equation (7) ensures that the required electricity is met by the allocated capacity. The year $t$ capacity is linked to year $t-1$ capacity by equation (9). This is to ensure that the capacity allocated in each year, included what was existing in the previous year. The required electricity per demand category was expanded in equation (8). This equation is introduced to differentiate the required electricity that is met by the base load technologies from the peak load technologies as shown in Table 3.

Hydro under base demand category in Table 3 is classified as mid merit energy fuel source in [16]. Solar and wind are classified as non-dispatchables in [16]. The demand forecast 


\begin{tabular}{ll}
\hline Base & Peak \\
\hline Coal & Hydro (pumped storage) \\
Hydro & Gas/Diesel \\
Nuclear & \\
Solar & \\
Wind & \\
\hline
\end{tabular}

Table 3: Fuel demand categories.

used in this study was taken from [37] and was not categorised into mid merit and nondispatchables. Hence hydro, wind and solar are classified as base. However, wind and solar have low capacity factors as shown in Table 2, which will be able to counteract the base demand category used. Equation (16) to equation (21) are for existing power plants.

$$
\begin{aligned}
\sum_{k} \boldsymbol{y}_{\text {pop }, k}^{t} \leq e_{\text {pop }}^{t} \text { cap } f_{\text {pop }}^{t} & \forall(t, \text { pop }), \\
e_{\text {pop }}^{t}=e_{\text {pop }}^{t-1}-d e c_{\text {pop }}^{t-1} & \forall(t, p o p), \\
\boldsymbol{d} \boldsymbol{u}_{k}^{t} \sum_{p o p} \boldsymbol{y}_{\text {pop }, k}^{t}=\boldsymbol{r}_{k}^{t} & \forall(t, k), \\
\boldsymbol{y}_{\text {pop }, k}^{t} \geq 0 & \forall(t, p o p, k), \\
e_{p o p}^{t} \geq 0 & \forall(t, p o p), \\
d e c_{p o p}^{t} \geq 0 & \forall(t, p o p) .
\end{aligned}
$$

Where:

- $p o p$ is power plant.

- $d e c_{p o p}^{t}$ is the decommissioned capacity for plant type pop at time $t$, as defined for new capacity.

All the other variables, parameters and indices in equation (16) to equation (21) are as defined for new technologies but used for existing power plants. It should be noted that no running costs were allocated to existing power plants, because existing capacity running costs were expensive compared to new technologies. The existing power plants are used to make sure that the model allocates electricity demand between existing power plants and new technology.

\subsection{Cost of unserved energy}

The cost of unserved energy (COUE) which emanates from load shedding, was referred to as backstop technology by Birge \& Louveaux [5] and import cost by Bisschop [6]. Load shedding is a controlled way of reducing the electricity demand, with the aim of protecting the electricity system from a total blackout [14]. COUE is the opportunity cost to electricity consumers and the economy from electricity supply interruptions [37]. The COUE is represented by $c u e^{t}$, which is in the first term of equation (11). The COUE is supposed to be higher than other running costs according to Bisschop and Birge \& Louveaux. 
A COUE of R75 per kWh was used in [37]. This COUE was revised by the National Energy Regulator of South Africa's (NERSA's) consultation paper [29]. The revised COUE of R87.85 per kWh which was taken from appendix A of the NERSA's consultation paper [29], is used in this paper.

\subsubsection{Cost of load shedding to electricity consumers}

According to the definition of load shedding in Section 5.2, load shedding affects both the electricity consumers and the economy. This section focuses on the cost of the recent past load shedding to the electricity consumers (COUE-1). In the recent past four stages of load shedding were experienced in South Africa. The four stages are presented in Table 4. The data with actual load shedding days and stages that were implemented by

\begin{tabular}{|c|c|c|c|c|}
\hline Stage & $\begin{array}{l}\text { Maximum } \\
\text { capacity } \\
\text { (MW) }\end{array}$ & Description & $\begin{array}{l}\text { Average } \\
\text { hours per day }\end{array}$ & $\begin{array}{l}\text { Maximum } \\
\text { kWh per day }\end{array}$ \\
\hline 1 & 1000 & $\begin{array}{l}3 \text { times over } \\
8 \text { day period for } \\
4 \text { hours at a time. }\end{array}$ & 1.5 & 1500000 \\
\hline 2 & 2000 & $\begin{array}{l}6 \text { times over } \\
8 \text { day period for } \\
4 \text { hours at a time. }\end{array}$ & 3 & 6000000 \\
\hline 3 & 3000 & $\begin{array}{l}9 \text { times over } \\
8 \text { day period for } \\
4 \text { hours at a time. }\end{array}$ & 4.5 & 13500000 \\
\hline 4 & 4000 & $\begin{array}{l}12 \text { times over } \\
8 \text { day period for } \\
4 \text { hours at a time. }\end{array}$ & 6 & 24000000 \\
\hline
\end{tabular}

Table 4: Load shedding stages [14].

the South African public electricity utility in the financial year 1 April 2018 to 31 March 2019 (2018/19) is in Appendix K. The information in Appendix K was used to calculate the actual number of days where a load shedding stage was implemented.

\begin{tabular}{crrr}
\hline Stages & Actual kWh & COUE-1 (R) & COUE-1 (R/kWh) \\
\hline 1 & 9000000 & 790650000 & 527.10 \\
2 & 72000000 & 6325200000 & 1054.20 \\
3 & 27000000 & 2371950000 & 175.70 \\
4 & 168000000 & 14758800000 & 614.95 \\
\hline
\end{tabular}

Table 5: Cost of load shedding to electricity consumers.

The actual number of days were multiplied with the corresponding maximum $\mathrm{kWh}$ per day from Table 4, this product is called actual $\mathrm{kWh}$ in Table 5 . The actual $\mathrm{kWh}$ values were multiplied by the COUE value of $87.85 \mathrm{R} / \mathrm{kWh}$, this product is called COUE- 1 (Rand (R)) in Table 5 . The quotient in the last column of Table 5 is COUE- 1 in R/kWh for each day where corresponding load shedding was implemented. The values in the last column of Table 5 were added to the cost of load shedding to the economy which is discussed in Section 5.2.2 and which were used in the model. 


\subsubsection{Cost of load shedding to the economy}

In Section 5.2 it was discussed that electricity interruptions do not only affect the electricity consumer, but also the economy. This section focuses on the cost of the recent past load shedding to the economy. According to Investec's chief economist, Annabel Bishop, the load shedding that was implemented in the first quarter of 2019 in South Africa could wipe off between $33 \%$ and $50 \%$ of the gross domestic product (GDP) [55]. Bishop's claim was used to calculate the cost of load shedding to the economy for the period in Appendix K. To be conservative $33 \%$ was used.

For the load shedding period under consideration, corresponding quarterly GDP in Rand (R) was taken from the Statistics South Africa GDP report for the fourth quarter of 2018 [43]. The monthly GDP (R) was estimated by interpolating quarterly GDP using cubic splines function in Matlab [8]. Monthly GDP for December 2018 was also used for February and March 2019, because GDP for the first quarter of 2019 is not published yet. The daily GDP (R) was derived by dividing the monthly GDP by the number of days in each month. The economic cost $(\mathrm{R})$ for each day of load shedding was derived by multiplying the daily GDP by $33 \%$. Then the economic cost (R) was added for all the days where the same loading shedding stage was implemented, the results are in the second column of Table 6 .

\begin{tabular}{crr}
\hline Stage & $\mathbf{3 3 \%}$ of daily GDP $(\mathbf{R})$ & COUE-2 $(\mathbf{R} / \mathbf{k W h})$ \\
\hline 1 & 51282677742 & 205131 \\
2 & 102774112673 & 205548 \\
3 & 18631564286 & 2760 \\
4 & 50527873497 & 14737 \\
\hline
\end{tabular}

Table 6: Cost of load shedding to the economy.

The values in the second column of Table 6 were divided by the corresponding maximum kWh per day in Table 4. The quotient was multiplied by the number of days for each loading stage. The results are in the last column of Table 6 , COUE-2 $(\mathrm{R} / \mathrm{kWh})$ for each day where corresponding load shedding stage was implemented. The COUE-2 (R/kWh) was added to the COUE-1 (R/kWh) in Table 5. The results are shown in Table 7 . These values were used in the model and the results are presented in Table 8.

\begin{tabular}{cr}
\hline Case & COUE-3 $(\mathbf{R} / \mathbf{k W h})$ \\
$\mathrm{A}$ & 2935.93 \\
$\mathrm{~B}$ & 15352.25 \\
$\mathrm{C}$ & 205657.81 \\
$\mathrm{D}$ & 206602.43 \\
\hline
\end{tabular}

Table 7: Cost of load shedding to electricity consumers and the economy.

However, it should be noted that the COUE $-3(\mathrm{R} / \mathrm{kWh})$ in Table 7 cannot be used for other load shedding periods, because:

- the COUE -3 (R/kWh) values were derived from load shedding stages that implemented during the load period under consideration, 
- GDP values used change from period to period, and

- the economist's view might also be different for load shedding which might be implemented in the future.

However, if a higher percent of GDP was used, say greater than $33 \%$ but less or equal to $50 \%$, this percent of GDP would have resulted in higher values of COUE $-3(\mathrm{R} / \mathrm{kWh})$.

\section{Results and discussion}

In this section, results for new capacity capital costs and corresponding running costs are presented. The new capacity and its corresponding $\mathrm{CO}_{2}$ emissions are also presented.

\subsection{Costs for new capacity}

In this study, Advanced Interactive Multidimensional Modelling System (AIMMS) software was used in the modelling process. Solutions were computed by employing the commercial solver CPLEX 12.6. The determined costs are for the new capacity only as shown by the first term of the objective function in equation (5). Table 8 shows the capital costs, running costs and total cost, when a COUE values derived in Section 5.2 were used. The costs in Table 8 are for each element of $\xi=\mathrm{S} 1, \mathrm{~S} 2, \mathrm{~S} 3, \mathrm{~S} 4$, provided as part of the solution.

\begin{tabular}{|c|c|c|c|c|c|}
\hline Rand (billion) & S1 & S2 & S3 & S4 & Solution \\
\hline \multicolumn{6}{|c|}{ Case A } \\
\hline Capital Costs & 1532.61 & 1532.61 & 1532.61 & 1532.61 & \\
\hline Running costs excluding COUE & 0.37 & 0.49 & 0.79 & 1.17 & \\
\hline COUE costs & 0.00 & 0.00 & 724.26 & 1949.24 & \\
\hline Total & 1532.98 & 1533.10 & 2257.66 & 3483.01 & 2201.69 \\
\hline \multicolumn{6}{|c|}{ Case B } \\
\hline Capital Costs & 2746.55 & 2746.55 & 2746.55 & 2746.55 & \\
\hline Running costs excluding the COUE & 0.37 & 0.48 & 0.83 & 1.31 & \\
\hline COUE costs & 0.00 & 0.00 & 0.00 & 764.78 & \\
\hline Total Costs & 2746.92 & 2747.04 & 2747.39 & 3512.64 & 2938.50 \\
\hline \multicolumn{6}{|c|}{ Case C } \\
\hline Capital Costs & 3094.19 & 3094.19 & 3094.19 & 3094.19 & \\
\hline Running costs excluding the COUE & 0.36 & 0.47 & 0.81 & 1.28 & \\
\hline COUE costs & 0.00 & 0.00 & 0.00 & 0.00 & \\
\hline Total Costs & 3094.55 & 3094.66 & 3095.00 & 3095.47 & 3094.92 \\
\hline \multicolumn{6}{|c|}{ Case D } \\
\hline Capital Costs & 3094.19 & 3094.19 & 3094.19 & 3094.19 & \\
\hline Running costs excluding the COUE & 0.36 & 0.47 & 0.81 & 1.28 & \\
\hline COUE costs & 0.00 & 0.00 & 0.00 & 0.00 & \\
\hline Total Costs & 3094.55 & 3094.66 & 3095.00 & 3095.47 & 3094.92 \\
\hline
\end{tabular}

Table 8: SP total capital costs for new capacity. 
In Table 8 the running costs consist of $0 \%$ of the COUE (R) for:

- S1 and S2 in Case A.

- S1, S2 and S3 in Case B.

- All scenarios in Case C and D.

Table 8 shows that the capital costs are the same for all the elements of $\xi$ in each case. This is the case because the capital costs are the first stage optimal results. For all the cases the running costs for S1 are the lowest compared to other scenarios, this was also expected because of the low electricity demand for S1. The results in Table 8 show that the solution to the objective function i.e. equation (5) is increasing from R2 201.69 billion in Case A to R3 094.92 in Cases C and D. The increase in objective function value is due to the increasing capital costs which is a result of high demand. However, one should bare in mind that the optimistic demand scenarios with equal probabilities and constant capacity factors were used when determining the results in Table 8.

The COUE results in Table 8 show that initially the model did not add new capacity, instead the COUE was used, hence COUE values are greater than zero for S3 and S4 in Case A, and S4 in Case B.

The results in Table 8 show that the COUE $(\mathrm{R})$ decreased with increasing value of COUE $(\mathrm{R} / \mathrm{kWh})$. However, the COUE $(\mathrm{R})$ did not decrease further for Case D. Table 8 also shows that any COUE $(\mathrm{R} / \mathrm{kWh})$ greater than Case C's will produce the same results as Case C. This was observed in Case D results. Results similar to $\mathrm{C}$ would have been obtained if the COUE -3 (R/kWh) values were derived from a GDP percent higher than $33 \%$.

\subsection{New capacity for SP model}

In this section the new capacity corresponding to the capital costs discussed in Section 6.1 is presented. The model increased capacity because of more demand than the existing capacity. Existing capacity kept on decreasing even after the installation of committed capacity as shown in Appendix B, due to decommissioned power plants as shown in Appendices $\mathrm{C}$ to $\mathrm{E}$.

Table 9, Table 10 and Table 11 show new capacity according to the technologies, $x_{p}^{t}$, based on sources of energy. As an example, the second column of Table 9 is the sum of $x_{p}^{t}$ from technology $p$ which use coal energy source as shown in Appendix F. The corresponding years, $t$, are in the first column.

It can be seen in Table 9 that new capacity started in 2026 with hydro energy sources. The hydro capacity was increased in 2031, where the wind energy capacity also started. The coal energy source capacity started in 2036 and then gas/diesel energy source capacity started in 2042. The total capacity for Case A kept increasing until 2045 and remained constant till the end of the period.

Unlike in Table 9, Table 10 shows that:

- new capacity started in 2021, with both gas/diesel and hydro energy sources;

- wind energy source came a year earlier. 


\begin{tabular}{rrrrrr}
\hline Year & Coal & Gas/Diesel & Wind & Hydro & Total \\
\hline 2026 & 0.00 & 0.00 & 0.00 & 1.36 & 1.36 \\
2027 & 0.00 & 0.00 & 0.00 & 1.36 & 1.36 \\
2028 & 0.00 & 0.00 & 0.00 & 1.36 & 1.36 \\
2029 & 0.00 & 0.00 & 0.00 & 1.36 & 1.36 \\
2030 & 0.00 & 0.00 & 0.00 & 1.36 & 1.36 \\
2031 & 0.00 & 0.00 & 12.14 & 3.53 & 15.68 \\
2032 & 0.00 & 0.00 & 12.14 & 3.84 & 15.98 \\
2033 & 0.00 & 0.00 & 12.14 & 7.68 & 19.82 \\
2034 & 0.00 & 0.00 & 12.14 & 7.68 & 19.82 \\
2035 & 0.00 & 0.00 & 12.14 & 7.68 & 19.82 \\
2036 & 9.91 & 0.00 & 19.20 & 7.68 & 36.79 \\
2037 & 21.43 & 0.00 & 19.20 & 7.68 & 48.31 \\
2038 & 24.12 & 0.00 & 19.20 & 7.68 & 51.00 \\
2039 & 28.20 & 0.00 & 19.20 & 7.68 & 55.08 \\
\hline 2040 & 34.58 & 0.00 & 19.20 & 7.68 & 61.46 \\
2041 & 37.16 & 0.00 & 19.20 & 7.68 & 64.04 \\
2042 & 37.16 & 0.52 & 19.20 & 7.68 & 64.56 \\
2043 & 37.16 & 5.31 & 19.20 & 7.68 & 69.36 \\
2044 & 37.16 & 5.31 & 19.20 & 7.68 & 69.36 \\
2045 & 37.16 & 5.56 & 19.20 & 7.68 & 69.61 \\
\hline 2046 & 37.16 & 5.56 & 19.20 & 7.68 & 69.61 \\
2047 & 37.16 & 5.56 & 19.20 & 7.68 & 69.61 \\
\hline 2048 & 37.16 & 5.56 & 19.20 & 7.68 & 69.61 \\
2049 & 37.16 & 5.56 & 19.20 & 7.68 & 69.61 \\
\hline 2050 & 37.16 & 5.56 & 19.20 & 7.68 & 69.61 \\
\hline & & & & & \\
\hline
\end{tabular}

Table 9: Case A: SP new capacity per technology $(G W)$.

The annual capacity allocation, $y_{p k}^{t}$ and $y_{p o p, k}^{t}$, results are shown in Figure 3 for Case A. For Case A, $y_{p k}^{t}$ is based on the new capacity in Table 9, however $y_{p o p, k}^{t}$ is based on existing power plants and committed capacity in Appendix A and Appendix B, respectively. Most of the existing capacity is decommissioned during the investigation period as shown in Appendix C to Appendix E.

Figure 3 shows the total capacity allocated to the demand categories $k$, for each year, $t$. The total capacity allocation is guided by the forecasted demand scenarios in Figure 2 for all the four scenarios. Case B, C and D will also show results similar to Figure 3.

Comparing Table 11 to Table 9 and Table 10:

- Similar to Table 9, hydro energy source capacity was installed first by the model. However, this capacity featured as early as 2014.

- The wind energy source capacity came next, but much earlier than in Cases A and B.

- Similar to Cases A and B, coal energy capacity featured in 2036.

- Unlike in Cases A and B, nuclear energy source capacity came after coal.

- Similar to Case A gas/diesel energy source capacity came last, but much later when compared to Case A.

Wind and hydro are the only renewable energy sources the model selected for all cases. The objective function of the model used in this paper minimises costs. As a result the 


\begin{tabular}{rrrrrr}
\hline Year & Coal & Gas/Diesel & Wind & Hydro & Total \\
\hline 2021 & 0.00 & 2.27 & 0.00 & 2.18 & 4.45 \\
2022 & 0.00 & 2.27 & 0.00 & 2.18 & 4.45 \\
2023 & 0.00 & 2.27 & 0.00 & 2.18 & 4.45 \\
2024 & 0.00 & 2.27 & 0.00 & 2.18 & 4.45 \\
2025 & 0.00 & 2.27 & 0.00 & 2.18 & 4.45 \\
2026 & 0.00 & 2.27 & 0.00 & 2.18 & 4.45 \\
2027 & 0.00 & 2.27 & 0.00 & 2.18 & 4.45 \\
2028 & 0.00 & 2.27 & 0.00 & 2.18 & 4.45 \\
2029 & 0.00 & 2.27 & 0.00 & 2.18 & 4.45 \\
2030 & 0.00 & 2.27 & 12.14 & 2.18 & 16.59 \\
2031 & 0.00 & 2.27 & 12.14 & 3.12 & 17.54 \\
2032 & 0.00 & 2.27 & 12.14 & 3.43 & 17.84 \\
2033 & 0.00 & 2.27 & 12.14 & 7.68 & 22.09 \\
2034 & 0.00 & 2.27 & 12.14 & 7.68 & 22.09 \\
\hline 2035 & 0.00 & 2.27 & 12.14 & 7.68 & 22.09 \\
2036 & 21.43 & 2.27 & 19.20 & 7.68 & 50.58 \\
2037 & 32.95 & 2.27 & 19.20 & 7.68 & 62.10 \\
2038 & 34.58 & 2.27 & 19.20 & 7.68 & 63.73 \\
2039 & 34.58 & 2.27 & 19.20 & 7.68 & 63.73 \\
2040 & 34.58 & 2.27 & 19.20 & 7.68 & 63.73 \\
\hline 2041 & 36.09 & 2.27 & 19.20 & 7.68 & 65.24 \\
2042 & 37.78 & 2.27 & 19.20 & 7.68 & 66.93 \\
\hline 2043 & 39.79 & 5.56 & 19.20 & 7.68 & 72.23 \\
2044 & 43.45 & 5.56 & 19.20 & 7.68 & 75.89 \\
\hline 2045 & 46.76 & 5.56 & 19.20 & 7.68 & 79.20 \\
2046 & 64.13 & 5.56 & 19.20 & 7.68 & 96.58 \\
2047 & 64.13 & 5.56 & 19.20 & 7.68 & 96.58 \\
\hline 2048 & 64.13 & 5.56 & 19.20 & 7.68 & 96.58 \\
\hline 2049 & 64.13 & 5.56 & 19.20 & 7.68 & 96.58 \\
2050 & 64.13 & 5.56 & 19.20 & 7.68 & 96.58 \\
\hline & & & & & \\
\hline
\end{tabular}

Table 10: Case B: SP new capacity per technology $(G W)$.

model did not select technologies that use renewable energy with high costs. The costs for renewable energy sources' technologies are in Appendices H, I and J. It can be observed that wind technology was cheaper when compared to solar technologies. Also wind had a higher capacity factor compared to solar renewable energy source as shown in Table 2.

Case C and D also had capacity from nuclear energy source. Nuclear energy source in Appendix G has expensive capital costs but lower fixed costs and a higher capacity factor when compared to solar energy sources in Appendices H and I.

The data used in this study was collected before 2013, when solar technologies were still expensive. However, the solar PV prices have fallen by $80 \%$ between 2009 and 2017 [13]. The model was not adjusted with new data for PV prices because there was no latest comprehensive data as shown in appendices at the time of writing this paper. Unlike the PV technology there were no actual price decrease statistics for CSP technology in literature. This is possibly the case since according to the International Energy Agency (IEA), only 6 countries worldwide had installed the CSP technology by 2017. However, IEA expected the CSP technology uptake to increase from 2018 to 2023. 


\begin{tabular}{|c|c|c|c|c|c|c|}
\hline Year & Coal & Nuclear & Gas/Diesel & Wind & Hydro & Total \\
\hline 2014 & 0.00 & 0.00 & 0.00 & 0.00 & 2.59 & 2.59 \\
\hline 2015 & 0.00 & 0.00 & 0.00 & 0.00 & 2.59 & 2.59 \\
\hline 2016 & 0.00 & 0.00 & 0.00 & 0.00 & 2.59 & 2.59 \\
\hline 2017 & 0.00 & 0.00 & 0.00 & 0.00 & 2.59 & 2.59 \\
\hline 2018 & 0.00 & 0.00 & 0.00 & 0.00 & 2.59 & 2.59 \\
\hline 2019 & 0.00 & 0.00 & 0.00 & 0.00 & 2.59 & 2.59 \\
\hline 2020 & 0.00 & 0.00 & 0.00 & 0.00 & 2.59 & 2.59 \\
\hline 2021 & 0.00 & 0.00 & 0.00 & 0.00 & 3.53 & 3.53 \\
\hline 2022 & 0.00 & 0.00 & 0.00 & 0.00 & 3.53 & 3.53 \\
\hline 2023 & 0.00 & 0.00 & 0.00 & 0.00 & 3.53 & 3.53 \\
\hline 2024 & 0.00 & 0.00 & 0.00 & 19.20 & 3.53 & 22.73 \\
\hline 2025 & 0.00 & 0.00 & 0.00 & 19.20 & 3.53 & 22.73 \\
\hline 2026 & 0.00 & 0.00 & 0.00 & 19.20 & 3.53 & 22.73 \\
\hline 2027 & 0.00 & 0.00 & 0.00 & 19.20 & 3.53 & 22.73 \\
\hline 2028 & 0.00 & 0.00 & 0.00 & 19.20 & 3.53 & 22.73 \\
\hline 2029 & 0.00 & 0.00 & 0.00 & 19.20 & 3.53 & 22.73 \\
\hline 2030 & 0.00 & 0.00 & 0.00 & 19.20 & 3.53 & 22.73 \\
\hline 2031 & 0.00 & 0.00 & 0.00 & 19.20 & 3.53 & 22.73 \\
\hline 2032 & 0.00 & 0.00 & 0.00 & 19.20 & 3.84 & 23.04 \\
\hline 2033 & 0.00 & 0.00 & 0.00 & 19.20 & 3.84 & 23.04 \\
\hline 2034 & 0.00 & 0.00 & 0.00 & 19.20 & 3.84 & 23.04 \\
\hline 2035 & 0.00 & 0.00 & 0.00 & 19.20 & 3.84 & 23.04 \\
\hline 2036 & 9.91 & 0.00 & 0.00 & 19.20 & 7.68 & 36.79 \\
\hline 2037 & 21.43 & 0.00 & 0.00 & 19.20 & 7.68 & 48.31 \\
\hline 2038 & 24.12 & 0.00 & 0.00 & 19.20 & 7.68 & 51.00 \\
\hline 2039 & 27.46 & 0.72 & 0.00 & 19.20 & 7.68 & 55.05 \\
\hline 2040 & 34.58 & 1.76 & 0.00 & 19.20 & 7.68 & 63.22 \\
\hline 2041 & 34.58 & 1.76 & 0.00 & 19.20 & 7.68 & 63.22 \\
\hline 2042 & 35.95 & 1.76 & 0.00 & 19.20 & 7.68 & 64.59 \\
\hline 2043 & 37.96 & 1.76 & 0.00 & 19.20 & 7.68 & 66.60 \\
\hline 2044 & 49.03 & 1.76 & 0.00 & 19.20 & 7.68 & 77.67 \\
\hline 2045 & 60.55 & 1.76 & 0.00 & 19.20 & 7.68 & 89.19 \\
\hline 2046 & 60.55 & 1.76 & 0.00 & 19.20 & 7.68 & 89.19 \\
\hline 2047 & 69.16 & 1.76 & 0.00 & 19.20 & 7.68 & 97.80 \\
\hline 2048 & 69.16 & 1.76 & 0.00 & 19.20 & 7.68 & 97.80 \\
\hline 2049 & 69.16 & 1.76 & 3.29 & 19.20 & 7.68 & 101.10 \\
\hline 2050 & 69.16 & 1.76 & 5.56 & 19.20 & 7.68 & 103.37 \\
\hline
\end{tabular}

Table 11: Case $C \& D: S P$ new capacity per technology $(G W)$.

Table 12 shows the energy sources' percentage allocation for 2013 and for the new and existing capacity (total capacity) as at 2050 for each case. The total capacity is dominated by coal for all cases. However, this is clean coal since the underlying coal technologies have carbon capture and storage (CCS) and flue gas desulphurisation (FGD) [23].

It can be observed in Table 12 that from 2013 to 2050 there is a capacity shift from coal, nuclear and other for all cases. The shifted capacity moved to wind and hydro in Case A. However in Cases B, C and D, the new capacity for coal increased from $59 \%$ to $68 \%$. The wind allocation decreased with increasing coal allocation for Cases B, C and D. In Cases $\mathrm{C}$ and D, nuclear's allocation increased when compared to Cases A and B. 


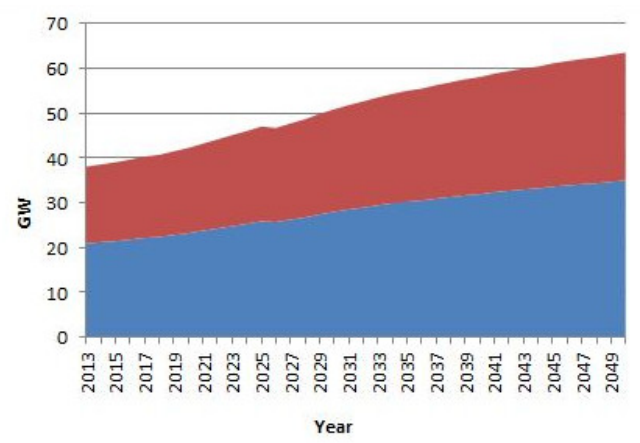

(a) Case A - S1.

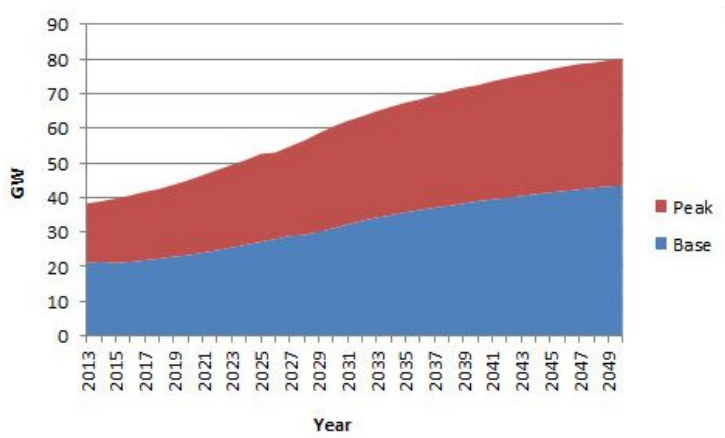

(c) Case A - S3.
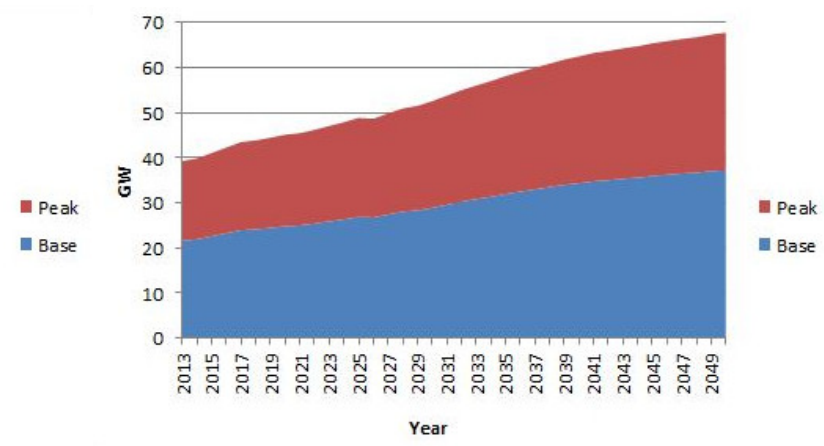

(b) Case A - S2.

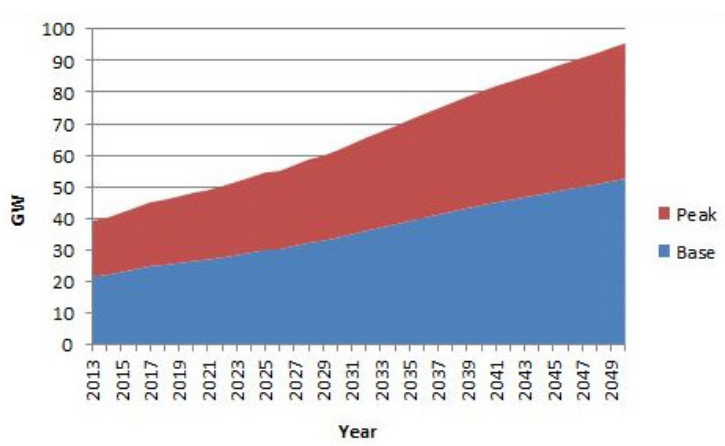

(d) Case A - S4.

Figure 3: Annual capacity allocation for Case A.

The challenge with the selected renewable energy sources is the intermittent nature of wind and hydro energy sources that are imported from Zambia and Mozambique as shown in appendix J. Hydro is imported since South Africa is one of the driest countries in the world, according to the South African Department of Water and Sanitation [61].

One should bear in mind that the electricity demand is slowing down in South Africa as shown in Figure 4 [12]. The declining electricity demand in South Africa has also been confirmed by the declining electricity sales as shown in Table 13.

If the trends shown by Figure 4 and Table 13 continue till the end of the investigation period and the actual electricity generation capacity expansion was based on more optimistic demand scenarios like S3 and S4, this would result in excessive electricity generation capacity surplus.

\section{3 $\mathrm{CO}_{2}$ emissions}

The general move from fossil fuels energy sources to renewable sources is driven by the agreement which was taken on the 21st session of the Conference of the Parties (COP21) [62]. According to Eskom's 2017/18 integrated report [15] historical electricity generation accounted for $42 \%$ of the nation's $\mathrm{CO}_{2}$ emission. In an effort to make sure that the country abide by the COP21 pledge, government departments have published the following documents: 


\begin{tabular}{lrrrr}
\hline Energy Source & $\mathbf{2 0 1 3}$ & Case A: 2050 (\%) & Case B: 2050 (\%) & Cases C \& D: 2050 (\%) \\
\hline Coal & 76 & 59 & 68 & 68 \\
Wind & 0 & 21 & 16 & 15 \\
Hydro & 8 & 14 & 11 & 10 \\
Gas/diesel & 5 & 6 & 5 & 4 \\
Nuclear & 4 & 0 & 0 & 1 \\
Other & 7 & 0 & 0 & 0 \\
\hline
\end{tabular}

Table 12: 2013 vs. 2050 SP total capacity allocation.

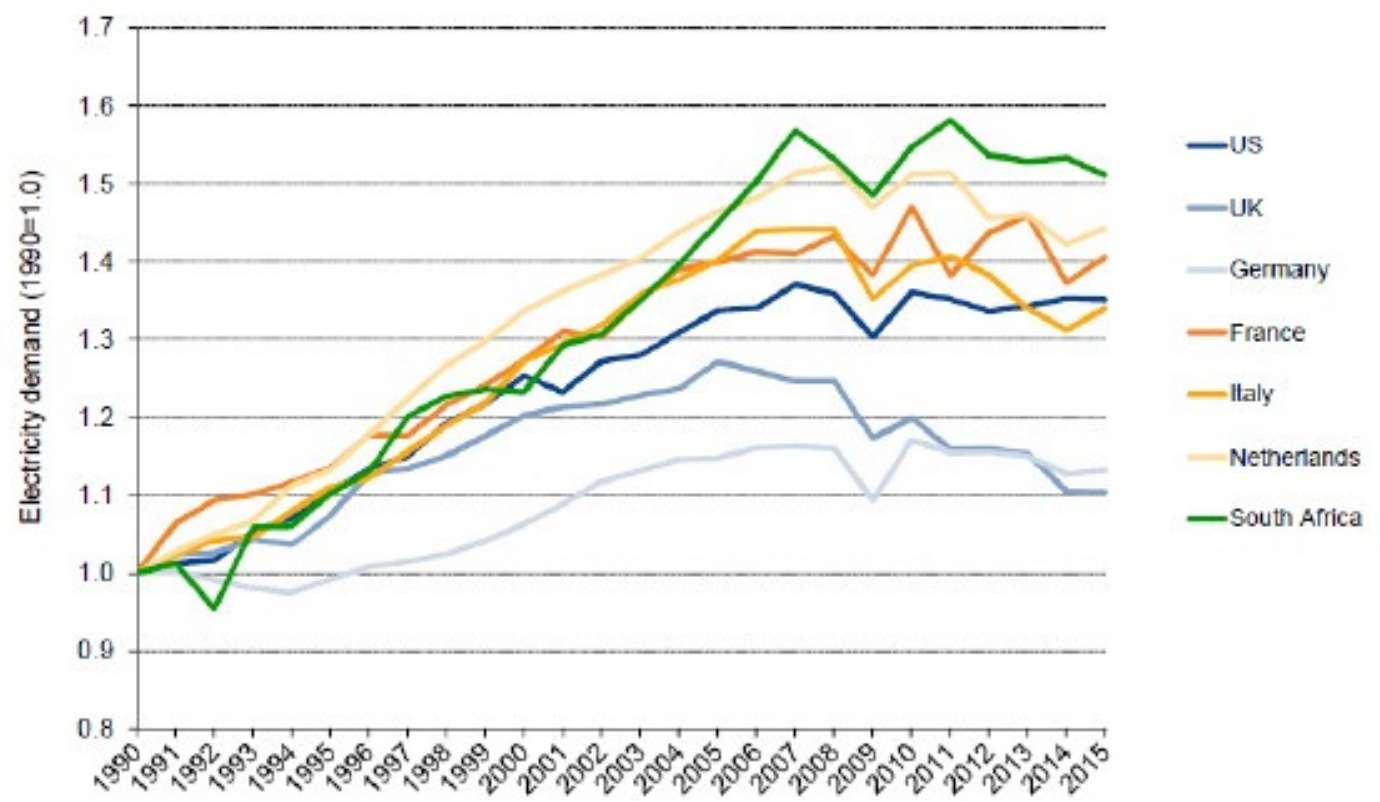

Figure 4: Historic electricity demand - SA vs. other countries [12].

\begin{tabular}{lr}
\hline Year & Growth (\%) \\
\hline $2012 / 13$ & -3.7 \\
$2013 / 14$ & 0.6 \\
$2014 / 15$ & -0.7 \\
$2015 / 16$ & -0.8 \\
$2016 / 17$ & -0.2 \\
$2017 / 18$ & -0.9 \\
\hline
\end{tabular}

Table 13: South African public utility total electricity sales growth[15].

- Department of Environmental Affairs (DEA) has gazetted a draft National greenhouse gas emission reporting regulations in June 2016 [39].

- DEA has also gazetted a climate change bill in June 2018 [41].

- South African National Treasury has published a carbon tax bill draft for public comments [60].

The $\mathrm{CO}_{2}$ emissions were determined only for the allocated new capacity. The model did not allocate the new capacity immediately. Hence the $\mathrm{CO}_{2}$ in Table 14 started later than 
2036, where the coal new capacity was introduced. Table 14 shows that $\mathrm{S} 1$ emit less $\mathrm{CO}_{2}$ compared to other scenarios. This is because S1 has less demand when compared to other scenarios. Some of S1 demand was met by renewable energy resources with no emission.

\begin{tabular}{rrrrrr}
\hline Year & S1 & S2 & S3 & S4 \\
\hline 2037 & 0 & 15222 & 69565 & 99017 \\
2038 & 0 & 22471 & 78166 & 111572 \\
2039 & 11989 & 36038 & 91747 & 141604 \\
2040 & 25687 & 50872 & 106624 & 210262 \\
2041 & 36909 & 61801 & 120146 & 253242 \\
2042 & 40115 & 64435 & 127034 & 268,753 \\
2043 & 44020 & 68246 & 145405 & 290229 \\
2044 & 55641 & 79730 & 194884 & 333707 \\
2045 & 65263 & 89090 & 231931 & 366428 \\
2046 & 132542 & 168451 & 280319 & 404048 \\
2047 & 144664 & 203435 & 314368 & 442539 \\
2048 & 206413 & 256220 & 363117 & 496807 \\
2049 & 231275 & 281593 & 386605 & 530560 \\
2050 & 265612 & 310989 & 414409 & 570594 \\
\hline
\end{tabular}

Table 14: Case A: Total $\mathrm{CO}_{2}$ emission per scenario (tonne).

\begin{tabular}{rrrrrr}
\hline Year & S1 & S2 & S3 & S4 \\
\hline 2037 & 0 & 15222 & 69565 & 99017 \\
2038 & 0 & 22471 & 78166 & 111572 \\
2039 & 11989 & 36038 & 91747 & 141604 \\
2040 & 25687 & 50872 & 106624 & 210262 \\
2041 & 36909 & 61801 & 120146 & 253242 \\
2042 & 40115 & 64435 & 127034 & 267248 \\
2043 & 44020 & 68246 & 145405 & 284804 \\
2044 & 55641 & 79730 & 194884 & 327459 \\
2045 & 65263 & 89090 & 231931 & 362119 \\
2046 & 132542 & 168451 & 276995 & 410868 \\
2047 & 144664 & 203435 & 312873 & 456195 \\
2048 & 206413 & 251141 & 364053 & 514948 \\
2049 & 231275 & 274627 & 389030 & 548701 \\
2050 & 262132 & 304848 & 418618 & 588735 \\
\hline
\end{tabular}

Table 15: Case B: Total $\mathrm{CO}_{2}$ emission per scenario (tonne).

For all the cases, $\mathrm{CO}_{2}$ emissions increase from 2037 to 2050 as shown in Table 14 to Table 16. Furthermore, $\mathrm{CO}_{2}$ emission also increase from $\mathrm{S} 1$ to $\mathrm{S} 4$.

However, $\mathrm{CO}_{2}$ emissions increased from Case A to Case $\mathrm{C}$ and $\mathrm{D}$. This is the case even though Table 12 showed that the coal energy source capacity was decreasing from Case A to Case C and D. The increased coal capacity observed for Case A is due to coal technologies with FGD. Appendix F shows that coal technology with FGD have high $\mathrm{CO}_{2}$ emissions and is cheaper when compared to coal technology with CCS.

South African long term emissions trajectory, "peak, plateau and decline", is for the entire country [40]. However, DEA derived the electricity supply sector "peak, plateau and decline" (PPD), from the country's as shown in Figure 5. 


\begin{tabular}{rrrrrr}
\hline Year & S1 & S2 & S3 & S4 \\
\hline 2037 & 0 & 15222 & 69565 & 99017 \\
2038 & 0 & 22471 & 78166 & 111572 \\
2039 & 11989 & 36038 & 91747 & 127658 \\
2040 & 25687 & 50872 & 106624 & 175905 \\
2041 & 36909 & 61801 & 120146 & 225246 \\
2042 & 40115 & 64435 & 124741 & 240608 \\
2043 & 44020 & 68246 & 126377 & 258163 \\
2044 & 55641 & 79730 & 160526 & 300819 \\
2045 & 65263 & 89090 & 197573 & 335894 \\
2046 & 132542 & 153698 & 250209 & 384083 \\
2047 & 143719 & 175241 & 286087 & 425250 \\
2048 & 172055 & 224501 & 337612 & 482804 \\
2049 & 203801 & 247986 & 362452 & 523338 \\
2050 & 235492 & 278207 & 391876 & 565714 \\
\hline
\end{tabular}

Table 16: Cases $C$ and D: Total $\mathrm{CO}_{2}$ emission per scenario (tonne).

Comparing the upper limit of Figure 5 in 2050 to Table 14, Table 15 and Table 16 2050's $\mathrm{CO}_{2}$ emissions, it looks like the scenarios are above the upper limit. However, $\mathrm{S} 1$ is close enough for all the cases. One must bear in mind that all the demand scenarios were optimistic about electricity demand, low electricity demand will help with lowering $\mathrm{CO}_{2}$ emissions.

The $\mathrm{CO}_{2}$ emissions recorded by the South African electricity public utility [15] in 2012/13 financial year was 227.9 million tons and 205.5 million tons in $2017 / 18$. According to Figure 5 the electricity public utility's emissions as at 2017/18 were between the lower and upper limits. However, as shown in Appendix A, the electricity public utility is not the only supplier of electricity.

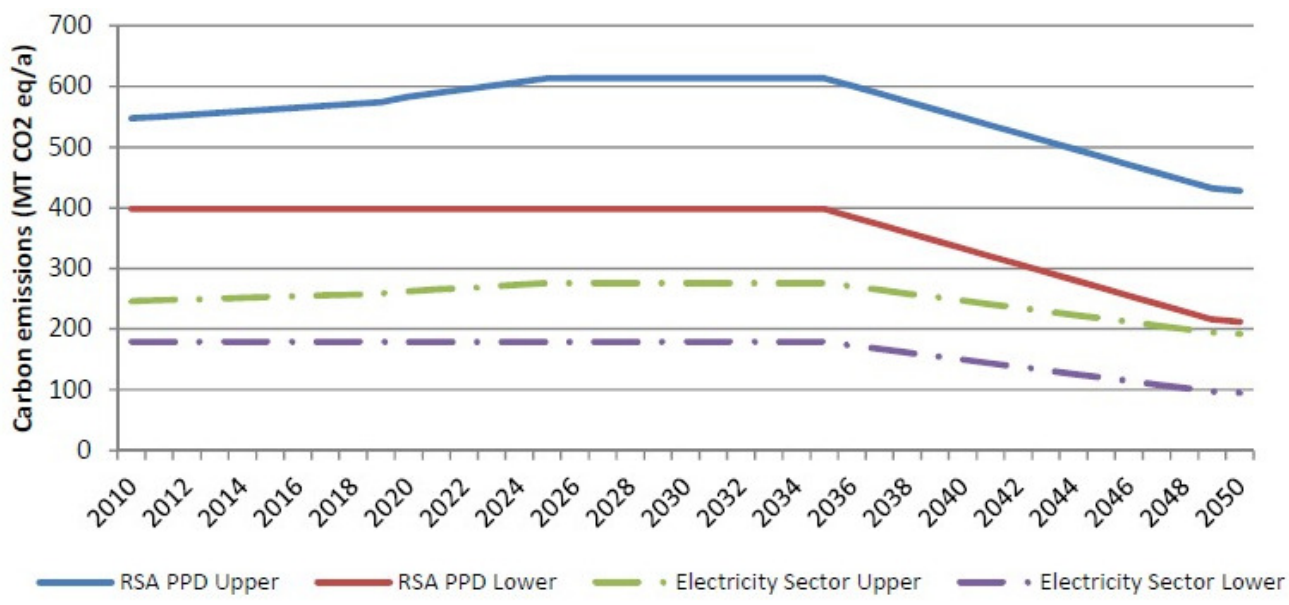

Figure 5: $\quad S A$ and electricity supply sector PPD [37]. 
According to the South African Department of Environmental Affairs (DEA) [40] electricity supply is the largest source of emissions. However, the electricity supplier can limit the emissions by shifting to lower carbon source of energy [40]. The emission results in Table 14, Table 15 and Table 16 show that the new capacity $\mathrm{CO}_{2}$ emissions in Section 6.2 will be above the upper limit by 2050. This is before including the existing capacity's $\mathrm{CO}_{2}$ emissions by 2050 .

In future work, $\mathrm{CO}_{2}$ emissions will be constrained in the model such that the new capacity emissions are aligned with DEA's recommendation of limiting emissions.

\section{Conclusion}

In this study TSSP modelling was applied to the South African electricity generation expansion planning for the first time. The random variable, $\xi$, was represented by four electricity demand scenarios, S1, S2, S3 and S4. Each demand scenario had $25 \%$ probability of occurring. As the actual demand is being realised the scenarios' probabilities can be adjusted to favour the most likely scenario. However, even though four scenarios were considered, the TSSP model incorporated all the scenarios at once. This resulted in optimal total costs ranging from R2 201 billion to R3 094 billion. The total costs from [37] range from R5 800 billion to R8 000 billion. However, these two sets of results are based on similar data up to an extent but assumptions, software and optimization models are not the same.

The costs constituencies as shown in Section 6 simplifies the decision makers' work because the capital costs are the same across all scenarios for each value of COUE (R/kWh) used; what changes per scenario are the running costs.

Results from Case A, S1 are considered to be more applicable, since these results are based on a more conservative demand scenario and have lower costs. Comparing 2013 and 2050 total capacities (existing and new) a decrease from coal, nuclear and other energy sources was observed. This decrease resulted in renewable energy sources' capacity increase. However, technologies that use solar renewable energy source were not selected because of high costs at the time when the data was collected and low capacity factors.

However, Case A's coal technologies emit more $\mathrm{CO}_{2}$. This can be resolved by constraining the $\mathrm{CO}_{2}$ emissions in the model.

An increased capacity from renewable energy sources in South Africa's electricity generation mix will contribute towards $\mathrm{CO}_{2}$ emissions decrease. This will assist the country in fulfilling the COP21 pledge.

\section{Acknowledgements}

The South African Department of Energy for publishing the data that was used for the IRP2010 update. The South African public electricity utility for supplying some of the data. AIMMS support team and Economics Technology Process employees for assisting in the AIMMS model development. 


\section{References}

[1] Amer M, Daim TU \& Jetter A, 2013, A review of scenario planning, Futures, 46, pp. 23-40.

[2] Albornoz VM, Benario P \& Rojas ME , 2004, A two-stage stochastic integer programming model for a thermal power system expansion, International Transactions in Operational Research, Vol.11, 243-257.

[3] Belardi P, Conforti D \& Violi A, 2008, A two-stage stochastic programming model for electric energy producers, Computers \& Operations Research, 35, pp. 3360-3370.

[4] Bellman R, 1953, An introduction to the theory of dynamic programming, [Online], [Cited 15 March 2019], Available from https://apps.dtic.mil/dtic/tr/fulltext/u2/074903.pdf.

[5] Birge JR \& Louveaux F, 2011, Introduction to Stochastic Programming, Springer, New York.

[6] Bisschop J, 1999, AIMMS Optimization Modeling, [online], [Cited 20 November 2017], Available from https://download.aimms.com/aimms/download/manuals/AIMMS3_0M.pdf.

[7] Calitz J, Mushwana C \& Bischof-Niemz T, 2017, Statistics of utility-scale solar PV, wind and CSP in South Africa in 2016, [online], [Cited 15 November 2017], Available from https://www.csir.co.za/sites/default/files/Documents/Statistics\%20of\%20Wind\% 20 and $\% 20$ Solar $\% 20$ PV $\% 20$ in $\% 20$ SA $\% 20$ in $\% 202016 \% 20-\% 20$ CSIR $\% 20-\% 20$ PUBLISHED . pdf.

[8] Columbia Economics, 2010, How Economists Convert Quarterly Data into Monthly: Cubic Spline Interpolation, [Online], [Cited 28 April 2019], Available from https://columbiaeconomics.com/2010/01/20/ how-economists-convert-quarterly-data-into-monthly-cubic-spline-interpolation/.

[9] Dantzig GB, 1955, Linear programming under uncertainty, Management Science, 1, pp. 197-206.

[10] Dantzig GB \& Infanger G, 1991, Large-scale stochastic linear programs: importance sampling and benders decomposition, [Online], [Cited 16 March 2019], Available from https://web.stanford. edu/group/SOL/reports/SOL-91-4.pdf.

[11] ENCA, 2018, Stage 2 load-shedding for Sunday, [Online], [Cited 21 April 2019], Available from https://www.enca.com/news/stage-2-load-shedding-sunday.

[12] Energy Intensive Users Group of Southern Africa, 2017, EIUG comments on on the IRP2016, [online], [Cited 17 October 2018], Available from http://eiug.org.za/wp-content/ uploads/2017/05/EIUG_IRP2016_Comment_20170331.pdf.

[13] ESI AfricA, 2017, Solar PV in Africa: Falling costs driving rapid growth, [Online], [Cited 3 March 2019], Available from https://www.esi-africa.com/industry-sectors/ renewable-energy/solar-pv-africa-falling-costs-driving-rapid-growth/.

[14] Esкom, Interpreting Schedules, [Online], [Cited 11 April 2019], Available from http:// loadshedding.eskom.co.za/loadshedding/ScheduleInterpretation.

[15] Eskom, 2017, Eskom integrated report, [online], [Cited 27 November 2017], Available from http: //www.eskom.co.za/IR2017/Pages/default.aspx.

[16] Esкom, 2018, Eskom integrated report, [online], [Cited 14 April 2018], Available from http://www. eskom.co.za/IR2018/Documents/Eskom2018IntegratedReport.pdf.

[17] Esкom, 2018, Eskom group interim results, [Online], [Cited 21 April 2019], Available from http: //www.eskom.co.za/IR2018/Interim/Pages/default.aspx.

[18] Esкom, 2019, Stage 2 loadshedding to continue until Sunday and the risk for loadshedding remains high until the middle of next week, [Online], [Cited 21 April 2019], Available from http://www.eskom. co.za/news/Pages/2019Mar15B . aspx. 
[19] Esкom, 2019, Eskom to continue with loadshedding, [Online], [Cited 21 April 2019], Available from http://www. eskom.co.za/news/Pages/2019Mar19B.aspx.

[20] Eye Witness News, 2019, Eskom to implement stage 2 load shedding on Sunday, [Online], [Cited 21 April 2019], Available from https://ewn.co.za/2019/02/10/ eskom-to-start-implementing-state-2-load-shedding-from-today.

[21] Eye Witness News,2019, Eskom shares the love with stage 2 load shedding for Thursday, [Online], [Cited 21 April 2019], Available from https://ewn.co.za/2019/02/14/ eskom-shares-the-love-with-stage-2-load-shedding-for-thursday.

[22] Higle JL, 2005, Stochastic programming: optimization when uncertainty matters, Tutorials in Operations Research, pp. 30-53.

[23] IEMA, 2015, From FGD to CCS, [Online], [Cited 3 March 2019], Available from https: //transform. iema.net/article/fgd/-ccs.

[24] IOL, 2018, Eskom implements Stage 2 load shedding until 10pm Monday, 2019, [Online], [Cited 21 April 2019], Available from https://www.iol.co.za/news/south-africa/western-cape/ eskom-escalates-load-shedding-to-stage-2-between-4pm-and-10pm-18345767.

[25] IOL, 2018, Eskom implements Stage 2 load shedding until 10pm Monday, [Online], [Cited 21 April 2019], Available from https://www.iol.co.za/news/south-africa/gauteng/ eskom-implements-stage-2-load-shedding-until-10pm-monday-18359801.

[26] IOL, 2018, Eskom implements Stage 1 rotational load shedding, [Online], [Cited 21 April 2019], Available from https://www.iol.co.za/news/south-africa/western-cape/ eskom-implements-stage-1-rotational-load-shedding-18430875.

[27] Lindgren M \& Bandhold H, 2003, Scenario planning - the link between future and strategy, Palgrave MacMillan, New York.

[28] Milligan M, Donohoo P \& O'Malley M, 2012, Stochastic methods for planning and operating power system with large amounts of wind and solar power, [Online], [Cited: 9 September 2017], Available from http://www.ourenergypolicy.org/wp-content/uploads/2012/09/56208.pdf.

[29] Nersa, 2017, Consultation paper - Framework for the cost of unserved energy for licensed electricity distributors, [Online], [Cited: 27 January 2019], Available from http://www.nersa.org.za/Admin/Document/Editor/file/Electricity/Consultation/ Documents/Consultation $\% 20$ Paper $\% 20$ on $\% 20$ the $\% 20$ Framework $\% 20$ for $\% 20$ the $\% 20$ Cost $\% 20$ of $\%$ 20Unserved\%20Energy \%20for\%20Licensed\%20Electricity\%20Distributors.pdf.

[30] Power 98.7, 2019, It's another day of load shedding, [Online], [Cited 21 April 2019], Available from https://www.power987.co.za/news/its-another-day-of-load-shedding/.

[31] Ridge Times, 2019, Power alert: Loadshedding moves to stage four, [Online], [Cited 21 April 2019], Available from https://ridgetimes.co.za/132248/ loadshedding-will-continue-today-throughout-entire-south-africa/.

[32] Shapiro A, Dentcheva D \& Ruszczynski A, 2009, Lectures on stochastic programming modelling and theory, SIAM, Philadelphia (PA).

[33] Schoemaker PJH, 1995, Scenario planning a tool for strategic thinking, MIT Sloan Management Review, 36, pp. 25-40.

[34] Sen S \& Zhou Z, 2011, Optimization simulation: The case of multi-stage stochastic decision models, Proceedings of the 2011 Winter Simulation Conference.

[35] Shahidehpour M \& Fu Y, 2003, Benders decomposition - applying Benders decomposition to power systems, IEEE Power \& Energy Magazine. 
[36] South African Department of Energy, 2011, Integrated Resource Plan for Electricity 20102030, [Online], [Cited 9 April 2018], Available from http://www.energy.gov.za/IRP/irp\%20files/ IRP2010_2030_Final_Report_20110325.pdf.

[37] South African Department of Energy, 2013, Integrated Resource Plan for Electricity 2010-2030 - Update Report 2013, [Online], [Cited 17 May 2018], Available from https://www .environment.gov . $\mathrm{za} /$ sites/default/files/docs/irp2010_2030.pdf.

[38] South African Department of Energy, Integrated resource plan, [Online], [Cited 21 December 2018], Available from http://www.energy.gov.za/IRP/overview.html.

[39] South African Department of Environmental Affairs, 2016, Draft national greenhouse gas emission reporting regulations, [Online], [Cited 14 November 2018], Available from https://cer.org.za/wp-content/uploads/2010/03/ Draft-National-Greenhouse-Gas-Emission-Reporting-Regulations .pdf.

[40] South African Department of Environmental Affairs, 2011, Opportunities for and costs of mitigation in South African economy, [Online], [Cited 20 March 2019], Available from https: //www.environment.gov.za/sites/default/files/docs/cost_mitigation_opportunities.pdf.

[41] South African Department of Environmental Affairs, 2016, Climate change bill, [Online], [Cited 14 November 2018], Available from https://www.environment.gov.za/sites/default/ files/legislations/climatechangebill2018_gn41689.pdf.

[42] Ireland G \& Jesse B, 2018, An assessment of new coal plants in South Africa's electricity future, [Online], [Cited 20 October 2019], Available from https://cer.org.za/programmes/pollution-climate-change/publications/ an-assessment-of-new-coal-plants-in-south-africas-electricity-future.

[43] Statistics South Africa, 2018, Gross domestic product second quarter 2018, [Online], [16 March 2019], Available from http://www.statssa.gov.za/publications/P0441/P04414thQuarter2018. pdf.

[44] The Forest of Brocéliande, Scenario analysis,[Online], [Cited 16 March 2019], Available from https://proxy.eplanete.net/galleries/broceliande7/scenario-analysis.

[45] The South African, 2018, Alert: Eskom implement "Stage 1 load shedding" for Sunday 18 November, [Online], [Cited 21 April 2019], Available from https://www.thesouthafrican.com/ eskom-load-shedding-schedule-who-is-affected-how-long-18-november/.

[46] The South African, 2018, Alert: Eskom confirm Stage 2 load shedding will stay in place until Friday, [Online], [Cited 21 April 2019], Available from https://ww.thesouthafrican.com/ eskom-load-shedding-tuesday-4-december-where-how-long/.

[47] The South African, 2018, Load shedding: Eskom keeps Stage 2 in place for Wednesday 5 December, [Online], [Cited 21 April 2019], Available from https://www.thesouthafrican.com/ load-shedding-wednesday-5-december-2018/.

[48] The South African, 2018, Load shedding: Eskom continues Stage 2 cuts on Thursday 6 December, [Online], [Cited 21 April 2019], Available from https://www.thesouthafrican.com/ load-shedding-thursday-6-december-2018/.

[49] The South African, 2018, Load shedding: Eskom keeps Stage 2 in place for Friday 7 December, [Online], [Cited 21 April 2019], Available from https://www.thesouthafrican.com/ load-shedding-friday-7-december-2018/.

[50] The South African, 2019, Load shedding: Eskom continues Stage 3 on Wednesday 13 February, [Online], [Cited 21 April 2019], Available from https://www.thesouthafrican.com/ load-shedding-wednesday-13-february-2019/. 
[51] The South African, 2019, Breaking: Eskom intensify load shedding, Stage 4 put in place until Sunday, [Online], [Cited 21 April 2019], Available from https://www.thesouthafrican.com/ load-shedding-stage-4-saturday-16-march-2019/.

[52] The South African, 2019, Load shedding: Eskom continues with Stage 4 on Sunday 17 March, [Online], [Cited 21 April 2019], Available from https://www.thesouthafrican.com/ load-shedding-today-17-march-2019/.

[53] The South African, 2019, Load shedding: Eskom holds Stage 4 in place on Wednesday 20 March, [Online], [Cited 21 April 2019], Available from https://www.thesouthafrican.com/ load-shedding-today-wednesday-20-march-2019/.

[54] The South African, 2019, Load shedding: Eskom drops to Stage 2 on Friday 22 March, [Online], [Cited 21 April 2019], Available from https://www.thesouthafrican.com/ load-shedding-today-friday-22-march-2019/.

[55] The South African, 2019, Eskom: Experts reveal how much money load shedding is costing South Africa, [Online], [Cited 1 May 2019], Available from https://www.thesouthafrican.com/ eskom-how-much-money-does-load-shedding-cost-south-africa/.

[56] Times Live, 2019, Stage 4 load-shedding continues on Monday, [Online], [Cited 21 April 2019], Available from https://www.timeslive.co.za/news/south-africa/ 2019-03-18-stage-4-load-shedding-continues-on-monday/.

[57] Times Live, 2019, SStage 4 load-shedding set to continue on Wednesday, [Online], [Cited 21 April 2019], Available from https://www.timeslive.co.za/news/south-africa/ 2019-03-19-stage-4-load-shedding-set-to-continue-on-wednesday/.

[58] Times Live, 2019, Load-shedding continues on Human Rights Day, [Online], [Cited 21 April 2019], Available from https://www.timeslive.co.za/news/south-africa/ 2019-03-21-load-shedding-continues-on-human-rights-day/.

[59] Times Live, 2019, Eskom continues with stage 2 load-shedding, [Online], [Cited 21 April 2019], Available from https://www.timeslive.co.za/news/south-africa/ 2019-03-23-eskom-continues-with-stage-2-load-shedding/.

[60] South African National Treasury, 2017, Draft carbon tax bill, [Online] [Cited 14 November 2018], Available from http://www.treasury.gov.za/publiccomments/CarbonTaxB112017/ DraftCarbonTaxBillDecember2017.pdf.

[61] South African Department of Water and Sanitation, Drought interventions, [Online], [Cited 9 February 2019], Available from http://www.dwa.gov.za/drought/.

[62] Un Framework Convention on Climate Change, 2015, Adoption of the Paris agreement, [Online], [Cited 14 November 2018], Available from http://www.cop21paris.org/about/cop21.

[63] US Energy Information Administration, 2019, Electric power monthly with data for July 2019,[Online], [Cited 20 October 2019], Available from https://www.eia.gov/electricity/ monthly/current_month/epm.pdf.

[64] Vespucci MT, Bertocchi M, Zigrino S \& Escuderob LF, 2013, Stochastic optimization models for power generation capacity expansion with risk management, 10th International Conference on European Energy Market, [Online], [Cited 28 October 2018], Available from https://ieeexplore. ieee.org/document/6607352.

[65] Wallace SW \& Fleten S, 2003, Stochastic programming models in energy, Handbooks in OR \& MS, 10. 
[66] WWF South Africa, 2015, Feasibility of the WWF renewable energy vision 2030 - South Africa, [Online], [Cited 28 October 2019], Available from http://www.wasaproject.info/docs/ WWFREVision2030Ju12015.pdf.

[67] Zahradnickova L \& VACIK E, 2014, Scenarios as a strong support for strategic planning, Procedia Engineering, 69, pp. 665-669 in 24th DAAAAM International Symposium on Intelligence Manufacturing and Automation, 2013.

[68] Zhu X \& Chow M, 1997, A review of emerging techniques on generation expansion planning, IEEE Transaction on Power Systems, 12, pp. 1722-1728. 


\section{Appendices}

\section{A. Existing capacity [37]}

\begin{tabular}{lrl}
\hline Plant name & $\begin{array}{l}\text { Capacity } \\
\text { (MW) }\end{array}$ & Source of energy \\
\hline Eskom & $\mathbf{4 2} \mathbf{3 3 0}$ & \\
\hline Camden & 1520 & Coal \\
Grootvlei & 1080 & Coal \\
\hline Komati & 900 & Coal \\
Arnot & 2220 & Coal \\
Hendrina & 1900 & Coal \\
Kriel & 2880 & Coal \\
Duvha & 3480 & Coal \\
Matla & 3480 & Coal \\
Kendal & 3840 & Coal \\
Lethabo & 3540 & Coal \\
Matimba & 3720 & Coal \\
Tutuka & 3540 & Coal \\
Majuba & 3840 & Coal \\
Koeberg & 1860 & Nuclear \\
Gariep & 360 & Hydro \\
Vanderkloof & 240 & Hydro \\
Colleywobbles & 70 & Hydro \\
Drakensberg & 1000 & Hydro \\
Palmiet & 400 & Hydro \\
Acacia & 180 & Gas/ Diesel \\
\hline Port Rex & 180 & Gas/ Diesel \\
Ankerlig & 1350 & Gas/ Diesel \\
Gourikwa & 750 & Gas/ Diesel \\
\hline Non-Eskom & $\mathbf{5 8 9 0}$ & \\
\hline Cahorra Bassa & 1500 & Hydro \\
\hline Aggreko & 90 & Gas \\
\hline Pretoria West & 90 & Coal \\
\hline Rooiwal & 180 & Coal \\
Sasol Infrachem & 150 & Gas \\
Sasol SSF & 500 & Coal \\
Steenbras & 180 & Hydro \\
Co-generation & 360 & Other \\
MTPPP & 280 & Other \\
DR Peaking & 500 & Other \\
Interruptible Load & 2060 & Other \\
\hline TOTAL & & \\
\hline & $\mathbf{4 8 0}$ & \\
\hline
\end{tabular}

Table 17: Existing capacity.

Where:

- SSF is Sasol synthetic fuel

- MTPPP is Eskom's medium term power purchase programme

- DR is demand response

- Hydro is hydroelectric and pumped storage 


\section{B. Committed capacity [37]}

The committed capacity was not yet built in 2013 but was already committed.

\begin{tabular}{rrrrrr}
\hline MW & Coal & Other & Gas & Wind & Other renewable \\
\hline 2010 & $\mathbf{3 8 0}$ & $\mathbf{2 6 0}$ & 0 & 0 & 0 \\
2011 & $\mathbf{6 7 9}$ & $\mathbf{1 3 0}$ & 0 & 0 & 0 \\
2012 & $\mathbf{3 0 3}$ & 0 & 0 & 400 & 100 \\
2013 & $\mathbf{8 2 3}$ & $\mathbf{3 3 3}$ & 1020 & 400 & 25 \\
2014 & $\mathbf{7 2 2}$ & $\mathbf{9 9 9}$ & 0 & 0 & 100 \\
2015 & $\mathbf{1 4 4 4}$ & 0 & 0 & 0 & 100 \\
2016 & $\mathbf{7 2 2}$ & 0 & 0 & 0 & 0 \\
2017 & $\mathbf{2} \mathbf{1 6 8}$ & 0 & 0 & 0 & 0 \\
2018 & $\mathbf{7 2 3}$ & 0 & 0 & 0 & 0 \\
2019 & $\mathbf{1} \mathbf{4 4 6}$ & 0 & 0 & 0 & 0 \\
2020 & $\mathbf{7 2 3}$ & 0 & 0 & 0 & 0 \\
\hline
\end{tabular}

Table 18: Committed capacity [37].

Where:

- The energy sources' capacities in bold are Eskom's commitments pre IRP.

- Other energy sources capacities which are not bold were committed in 2011 ministerial determinations.

- The wind energy source includes $100 \mathrm{MW}$ for Eskom's Sere plant. 


\section{Assumed decommissioning schedule - 1 [37]}

\begin{tabular}{|c|c|c|c|c|c|c|c|c|c|}
\hline $\begin{array}{l}\text { MW } \\
\text { Year }\end{array}$ & Arnot & Camden & Duvha & Grootvlei & Hendrina & Kendal & Komati & Kriel & Lethabo \\
\hline 2013 & 0 & 0 & 0 & 0 & 0 & 0 & 0 & 0 & 0 \\
\hline 2014 & 0 & 0 & 0 & 0 & 0 & 0 & 0 & 0 & 0 \\
\hline 2015 & 0 & 0 & 0 & 0 & 0 & 0 & 0 & 0 & 0 \\
\hline 2016 & 0 & 0 & 0 & 0 & 0 & 0 & 0 & 0 & 0 \\
\hline 2017 & 0 & 0 & 0 & 0 & 0 & 0 & 0 & 0 & 0 \\
\hline 2018 & 0 & 0 & 0 & 0 & 0 & 0 & 0 & 0 & 0 \\
\hline 2019 & 0 & 0 & 0 & 0 & 0 & 0 & 0 & 0 & 0 \\
\hline 2020 & 0 & 380 & 0 & 0 & 0 & 0 & 0 & 0 & 0 \\
\hline 2021 & 0 & 190 & 0 & 0 & 380 & 0 & 0 & 0 & 0 \\
\hline 2022 & 0 & 570 & 0 & 0 & 380 & 0 & 0 & 0 & 0 \\
\hline 2023 & 0 & 380 & 0 & 0 & 190 & 0 & 0 & 0 & 0 \\
\hline 2024 & 0 & 0 & 0 & 0 & 190 & 0 & 200 & 0 & 0 \\
\hline 2025 & 740 & 0 & 0 & 180 & 190 & 0 & 100 & 0 & 0 \\
\hline 2026 & 370 & 0 & 0 & 360 & 190 & 0 & 100 & 480 & 0 \\
\hline 2027 & 370 & 0 & 0 & 180 & 380 & 60 & 300 & 480 & 0 \\
\hline 2028 & 370 & 0 & 0 & 360 & 0 & 0 & 200 & 960 & 0 \\
\hline 2029 & 370 & 0 & 0 & 0 & 0 & 0 & 0 & 960 & 0 \\
\hline 2030 & 0 & 0 & 1160 & 0 & 0 & 0 & 0 & 0 & 0 \\
\hline 2031 & 0 & 0 & 580 & 0 & 0 & 0 & 0 & 0 & 0 \\
\hline 2032 & 0 & 0 & 580 & 0 & 0 & 0 & 0 & 0 & 0 \\
\hline 2033 & 0 & 0 & 580 & 0 & 0 & 0 & 0 & 0 & 0 \\
\hline 2034 & 0 & 0 & 580 & 0 & 0 & 0 & 0 & 0 & 0 \\
\hline 2035 & 0 & 0 & 0 & 0 & 0 & 0 & 0 & 0 & 590 \\
\hline 2036 & 0 & 0 & 0 & 0 & 0 & 0 & 0 & 0 & 590 \\
\hline 2037 & 0 & 0 & 0 & 0 & 0 & 0 & 0 & 0 & 0 \\
\hline 2038 & 0 & 0 & 0 & 0 & 0 & 630 & 0 & 0 & 0 \\
\hline 2039 & 0 & 0 & 0 & 0 & 0 & 0 & 0 & 0 & 1800 \\
\hline 2040 & 0 & 0 & 0 & 0 & 0 & 0 & 0 & 0 & 590 \\
\hline 2041 & 0 & 0 & 0 & 0 & 0 & 1890 & 0 & 0 & 590 \\
\hline 2042 & 0 & 0 & 0 & 0 & 0 & 630 & 0 & 0 & 0 \\
\hline 2043 & 0 & 0 & 0 & 0 & 0 & 630 & 0 & 0 & 0 \\
\hline 2044 & 0 & 0 & 0 & 0 & 0 & 0 & 0 & 0 & 0 \\
\hline 2045 & 0 & 0 & 0 & 0 & 0 & 0 & 0 & 0 & 0 \\
\hline 2046 & 0 & 0 & 0 & 0 & 0 & 0 & 0 & 0 & 0 \\
\hline 2047 & 0 & 0 & 0 & 0 & 0 & 0 & 0 & 0 & 0 \\
\hline 2048 & 0 & 0 & 0 & 0 & 0 & 0 & 0 & 0 & 0 \\
\hline 2049 & 0 & 0 & 0 & 0 & 0 & 0 & 0 & 0 & 0 \\
\hline 2050 & 0 & 0 & 0 & 0 & 0 & 0 & 0 & 0 & 0 \\
\hline
\end{tabular}

Table 19: Assumed decommissioning schedule - 1 [37]. 


\section{Assumed decommissioning schedule - 2 [37]}

\begin{tabular}{|c|c|c|c|c|c|c|c|c|c|}
\hline $\begin{array}{l}\text { MW } \\
\text { Year }\end{array}$ & Majuba & Matimba & Matla & Tutuka & Pretoria West & Rooiwal & Sasol Infrachem & Sasol SSF & Koeberg \\
\hline 2013 & 0 & 0 & 0 & 0 & 0 & 0 & 0 & 0 & 0 \\
\hline 2014 & 0 & 0 & 0 & 0 & 0 & 0 & 0 & 0 & 0 \\
\hline 2015 & 0 & 0 & 0 & 0 & 0 & 0 & 0 & 0 & 0 \\
\hline 2016 & 0 & 0 & 0 & 0 & 90 & 0 & 0 & 0 & 0 \\
\hline 2017 & 0 & 0 & 0 & 0 & 0 & 0 & 0 & 0 & 0 \\
\hline 2018 & 0 & 0 & 0 & 0 & 0 & 0 & 0 & 0 & 0 \\
\hline 2019 & 0 & 0 & 0 & 0 & 0 & 0 & 0 & 0 & 0 \\
\hline 2020 & 0 & 0 & 0 & 0 & 0 & 0 & 0 & 0 & 0 \\
\hline 2021 & 0 & 0 & 0 & 0 & 0 & 0 & 0 & 0 & 0 \\
\hline 2022 & 0 & 0 & 0 & 0 & 0 & 0 & 0 & 0 & 0 \\
\hline 2023 & 0 & 60 & 0 & 0 & 0 & 0 & 0 & 0 & 0 \\
\hline 2024 & 0 & 0 & 0 & 60 & 0 & 180 & 0 & 0 & 0 \\
\hline 2025 & 0 & 0 & 0 & 0 & 0 & 0 & 0 & 500 & 0 \\
\hline 2026 & 0 & 0 & 0 & 0 & 0 & 0 & 0 & 0 & 0 \\
\hline 2027 & 0 & 0 & 0 & 0 & 0 & 0 & 0 & 0 & 0 \\
\hline 2028 & 0 & 0 & 0 & 0 & 0 & 0 & 0 & 0 & 0 \\
\hline 2029 & 0 & 0 & 580 & 0 & 0 & 0 & 0 & 0 & 0 \\
\hline 2030 & 0 & 0 & 1160 & 0 & 0 & 0 & 0 & 0 & 0 \\
\hline 2031 & 0 & 0 & 580 & 0 & 0 & 0 & 0 & 0 & 0 \\
\hline 2032 & 0 & 0 & 580 & 0 & 0 & 0 & 0 & 0 & 0 \\
\hline 2033 & 0 & 0 & 580 & 0 & 0 & 0 & 0 & 0 & 0 \\
\hline 2034 & 0 & 0 & 0 & 0 & 0 & 0 & 0 & 0 & 0 \\
\hline 2035 & 0 & 0 & 0 & 580 & 0 & 0 & 0 & 0 & 0 \\
\hline 2036 & 0 & 0 & 0 & 1160 & 0 & 0 & 0 & 0 & 0 \\
\hline 2037 & 0 & 1220 & 0 & 580 & 0 & 0 & 0 & 0 & 0 \\
\hline 2038 & 0 & 610 & 0 & 580 & 0 & 0 & 0 & 0 & 0 \\
\hline 2039 & 0 & 610 & 0 & 0 & 0 & 0 & 0 & 0 & 0 \\
\hline 2040 & 0 & 610 & 0 & 580 & 0 & 0 & 0 & 0 & 0 \\
\hline 2041 & 0 & 610 & 0 & 0 & 0 & 0 & 0 & 0 & 0 \\
\hline 2042 & 0 & 0 & 0 & 0 & 0 & 0 & 0 & 0 & 0 \\
\hline 2043 & 0 & 0 & 0 & 0 & 0 & 0 & 150 & 0 & 0 \\
\hline 2044 & 0 & 0 & 0 & 0 & 0 & 0 & 0 & 0 & 1860 \\
\hline 2045 & 0 & 0 & 0 & 0 & 0 & 0 & 0 & 0 & 0 \\
\hline 2046 & 610 & 0 & 0 & 0 & 0 & 0 & 0 & 0 & 0 \\
\hline 2047 & 610 & 0 & 0 & 0 & 0 & 0 & 0 & 0 & 0 \\
\hline 2048 & 610 & 0 & 0 & 0 & 0 & 0 & 0 & 0 & 0 \\
\hline 2049 & 670 & 0 & 0 & 0 & 0 & 0 & 0 & 0 & 0 \\
\hline 2050 & 670 & 0 & 0 & 0 & 0 & 0 & 0 & 0 & 0 \\
\hline
\end{tabular}

Table 20: Assumed decommissioning schedule - 2 [37]. 


\section{E. Assumed decommissioning schedule - 3 [37]}

\begin{tabular}{|c|c|c|c|c|c|c|c|c|}
\hline $\begin{array}{l}\text { MW } \\
\text { Year }\end{array}$ & Acacia & Aggreko & Ankerlig & DoE IPP & Gourikwa & Port Rex & Co-generation & MTPPP \\
\hline 2013 & 0 & 0 & 0 & 0 & 0 & 0 & 0 & 0 \\
\hline 2014 & 0 & 90 & 0 & 0 & 0 & 0 & 0 & 0 \\
\hline 2015 & 0 & 0 & 0 & 0 & 0 & 0 & 0 & 0 \\
\hline 2016 & 0 & 0 & 0 & 0 & 0 & 0 & 0 & 0 \\
\hline 2017 & 0 & 0 & 0 & 0 & 0 & 0 & 0 & 0 \\
\hline 2018 & 0 & 0 & 0 & 0 & 0 & 0 & 0 & 0 \\
\hline 2019 & 0 & 0 & 0 & 0 & 0 & 0 & 0 & 0 \\
\hline 2020 & 0 & 0 & 0 & 0 & 0 & 0 & 0 & 0 \\
\hline 2021 & 0 & 0 & 0 & 0 & 0 & 0 & 0 & 0 \\
\hline 2022 & 0 & 0 & 0 & 0 & 0 & 0 & 0 & 0 \\
\hline 2023 & 0 & 0 & 0 & 0 & 0 & 0 & 0 & 0 \\
\hline 2024 & 0 & 0 & 0 & 0 & 0 & 0 & 0 & 0 \\
\hline 2025 & 0 & 0 & 0 & 0 & 0 & 0 & 0 & 0 \\
\hline 2026 & 180 & 0 & 0 & 0 & 0 & 180 & 0 & 0 \\
\hline 2027 & 0 & 0 & 0 & 0 & 0 & 0 & 0 & 0 \\
\hline 2028 & 0 & 0 & 0 & 0 & 0 & 0 & 0 & 0 \\
\hline 2029 & 0 & 0 & 0 & 0 & 0 & 0 & 0 & 0 \\
\hline 2030 & 0 & 0 & 0 & 0 & 0 & 0 & 0 & 0 \\
\hline 2031 & 0 & 0 & 0 & 0 & 0 & 0 & 0 & 0 \\
\hline 2032 & 0 & 0 & 0 & 0 & 0 & 0 & 0 & 0 \\
\hline 2033 & 0 & 0 & 0 & 0 & 0 & 0 & 0 & 0 \\
\hline 2034 & 0 & 0 & 0 & 0 & 0 & 0 & 0 & 0 \\
\hline 2035 & 0 & 0 & 0 & 0 & 0 & 0 & 0 & 0 \\
\hline 2036 & 0 & 0 & 0 & 0 & 0 & 0 & 360 & 0 \\
\hline 2037 & 0 & 0 & 1350 & 0 & 750 & 0 & 0 & 0 \\
\hline 2038 & 0 & 0 & 0 & 0 & 0 & 0 & 0 & 0 \\
\hline 2039 & 0 & 0 & 0 & 0 & 0 & 0 & 0 & 0 \\
\hline 2040 & 0 & 0 & 0 & 0 & 0 & 0 & 0 & 0 \\
\hline 2041 & 0 & 0 & 0 & 0 & 0 & 0 & 0 & 280 \\
\hline 2042 & 0 & 0 & 0 & 0 & 0 & 0 & 0 & 0 \\
\hline 2043 & 0 & 0 & 0 & 0 & 0 & 0 & 0 & 0 \\
\hline 2044 & 0 & 0 & 0 & 0 & 0 & 0 & 0 & 0 \\
\hline 2045 & 0 & 0 & 0 & 0 & 0 & 0 & 0 & 0 \\
\hline 2046 & 0 & 0 & 0 & 1020 & 0 & 0 & 0 & 0 \\
\hline 2047 & 0 & 0 & 0 & 0 & 0 & 0 & 0 & 0 \\
\hline 2048 & 0 & 0 & 0 & 0 & 0 & 0 & 0 & 0 \\
\hline 2049 & 0 & 0 & 0 & 0 & 0 & 0 & 0 & 0 \\
\hline 2050 & 0 & 0 & 0 & 0 & 0 & 0 & 0 & 0 \\
\hline
\end{tabular}

Table 21: Assumed decommissioning schedule - 3 [37]. 


\section{F. Coal technologies [37]}

Appendix F displays the new technology input data that was used in the model for technologies that use coal as a source of energy. The contents of this appendix were taken from the IRP update report [37].

\begin{tabular}{|c|c|c|c|c|c|c|}
\hline & $\begin{array}{l}\text { PC with } \\
\text { FGD }\end{array}$ & $\begin{array}{l}\text { PC with } \\
\text { CCS }\end{array}$ & $\begin{array}{l}\text { FBD with } \\
\text { FGD }\end{array}$ & $\begin{array}{l}\text { FBD with } \\
\text { CCS }\end{array}$ & IGCC & $\begin{array}{l}\text { IGCC } \\
\text { with CCS }\end{array}$ \\
\hline $\begin{array}{l}\text { Rated } \\
\text { capacity, net } \\
\text { (MW) }\end{array}$ & $\begin{array}{r}4500 \\
(750 \times 6)\end{array}$ & $\begin{array}{r}4500 \\
(750 \times 6)\end{array}$ & 250 & 250 & $\begin{array}{r}1288 \\
(644 \times 2)\end{array}$ & $\begin{array}{r}1288 \\
(644 \times 2)\end{array}$ \\
\hline $\begin{array}{l}\text { Adjusted } \\
\text { overnight } \\
\text { capital cost } \\
(\mathrm{R} / \mathrm{kW})\end{array}$ & 25772 & 48789 & 23661 & 44325 & 32340 & 43160 \\
\hline $\begin{array}{l}\text { Fixed O\&M } \\
\text { cost } \\
(\mathrm{R} / \mathrm{kW}) \text { per } \\
\text { year }\end{array}$ & 552 & 923 & 543 & 902 & 794 & 951 \\
\hline $\begin{array}{l}\text { Variable } \\
\text { O\&M cost } \\
\text { (R/MWh) }\end{array}$ & 51.2 & 81.4 & 110.8 & 149.1 & 42.5 & 65.4 \\
\hline $\begin{array}{l}\text { Variable fuel } \\
\text { cost }(\mathrm{R} / \mathrm{GJ})\end{array}$ & 17.5 & 17.5 & 8.75 & 8.75 & 17.5 & 17.5 \\
\hline $\begin{array}{l}\mathrm{CO}_{2} \\
\text { emissions } \\
(\mathrm{kg} / \mathrm{MWh})\end{array}$ & 947.3 & 136.2 & 978 & 150 & 930 & 120 \\
\hline
\end{tabular}

Table 22: Coal technologies [37].

Where:

- $\mathrm{PC}$ is pulverised coal

- FGD is flue gas desulphurisation

- CCS is carbon capture and storage

- FBD is fluidised bed combustion

- IGCC is integrated gasification combined cycle

- O\&M is operating and maintenance

- $\mathrm{kg} / \mathrm{MWh}$ is kilogram per megawatt hour 


\section{G. Nuclear and gas/diesel technologies [37]}

Appendix G displays the new technology input data that was used in the model for technologies that use nuclear and gas/diesel as a source of energy. The contents of this appendix were taken from the IRP update report [37].

\begin{tabular}{|c|c|c|c|c|c|}
\hline & $\begin{array}{l}\text { Nuclear } \\
\text { single unit }\end{array}$ & $\begin{array}{l}\text { Nuclear } \\
\text { fleet }\end{array}$ & OCGT & CCGT & $\begin{array}{l}\text { CCGT } \\
\text { with CCS }\end{array}$ \\
\hline $\begin{array}{l}\text { Rated } \\
\text { capacity, net } \\
\text { (MW) }\end{array}$ & 1600 & $\begin{array}{r}9600 \\
(1600 \times 6)\end{array}$ & 115 & 711 & 591 \\
\hline $\begin{array}{l}\text { Adjusted } \\
\text { overnight } \\
\text { capital cost } \\
(\mathrm{R} / \mathrm{kW})\end{array}$ & 58036 & 59226 & 4671 & 7089 & 14632 \\
\hline $\begin{array}{l}\text { Fixed O\&M } \\
\text { cost } \\
(\mathrm{R} / \mathrm{kW}) \text { per } \\
\text { year }\end{array}$ & 532 & 532 & 78 & 163 & 292 \\
\hline $\begin{array}{l}\text { Variable } \\
\text { O\&M cost } \\
(\mathrm{R} / \mathrm{MWh})\end{array}$ & 29.5 & 29.5 & 0.2 & 0.7 & 0.7 \\
\hline $\begin{array}{l}\text { Variable fuel } \\
\text { cost }(\mathrm{R} / \mathrm{GJ})\end{array}$ & 6.8 & 6.8 & 92 & 92 & 92 \\
\hline $\begin{array}{l}\mathrm{CO}_{2} \\
\text { emissions } \\
(\mathrm{kg} / \mathrm{MWh})\end{array}$ & 0 & 0 & 618 & 388 & 47 \\
\hline
\end{tabular}

Table 23: Nuclear and gas/diesel technologies [37].

Where:

- OCGT is open cycle gas turbines

- CCGT is closed cycle gas turbine 


\section{H. Technologies for renewable sources - 1 [37]}

Appendix $\mathrm{H}$ displays the new technology input data that was used in the model for technologies that use renewable sources of energy. The contents of this appendix were taken from the IRP update report [37].

\begin{tabular}{|c|c|c|c|c|}
\hline & Wind & $\begin{array}{l}\text { CSP } \\
\text { Parabolic } \\
\text { trough } 3 \mathrm{hrs}\end{array}$ & $\begin{array}{l}\text { CSP } \\
\text { Parabolic } \\
\text { trough } 6 \text { hrs }\end{array}$ & $\begin{array}{l}\text { CSP } \\
\text { Parabolic } \\
\text { trough 9hrs }\end{array}$ \\
\hline $\begin{array}{l}\text { Rated capacity, } \\
\text { net (MW) }\end{array}$ & $100(50 \times 2)$ & 125 & 125 & 125 \\
\hline $\begin{array}{l}\text { Adjusted } \\
\text { overnight capital } \\
\text { cost }(\mathrm{R} / \mathrm{kW})\end{array}$ & 15945 & 44626 & 56381 & 67512 \\
\hline $\begin{array}{l}\text { Fixed O\&M cost } \\
(\mathrm{R} / \mathrm{kW}) \text { per } \\
\text { year }\end{array}$ & 310 & 582 & 599 & 616 \\
\hline $\begin{array}{l}\text { Variable O\&M } \\
\text { cost (R/MWh) }\end{array}$ & 0 & 1.9 & 2 & 2 \\
\hline $\begin{array}{l}\text { Variable fuel } \\
\text { cost (R/GJ) }\end{array}$ & 0 & 0 & 0 & 0 \\
\hline $\begin{array}{l}\mathrm{CO}_{2} \text { emissions } \\
(\mathrm{kg} / \mathrm{MWh})\end{array}$ & 0 & 0 & 0 & 0 \\
\hline
\end{tabular}

Table 24: Technologies for renewable sources - 1 [37].

Where:

- CSP is Concentrated Solar Power 


\section{Technologies for renewable sources - 2 [37]}

Appendix I displays the new technology costs input data that were used in the model for technologies that use renewable energy sources. The contents of this appendix were taken from the IRP update report [37].

\begin{tabular}{|c|c|c|c|c|}
\hline & $\begin{array}{l}\text { CSP Central } \\
\text { receiver } 3 \mathrm{hrs}\end{array}$ & $\begin{array}{l}\text { CSP Central } \\
\text { receiver } 6 \mathrm{hrs}\end{array}$ & $\begin{array}{l}\text { CSP Central } \\
\text { receiver } 9 \mathrm{hrs}\end{array}$ & $\begin{array}{l}\text { PV Crystalline } \\
\text { silicon fixed tilt }\end{array}$ \\
\hline $\begin{array}{l}\text { Rated capacity, } \\
\text { net (MW) }\end{array}$ & 125 & 125 & 125 & 10 \\
\hline $\begin{array}{l}\text { Adjusted } \\
\text { overnight capital } \\
\text { cost }(\mathrm{R} / \mathrm{kW})\end{array}$ & 41469 & 49513 & 56949 & 29141 \\
\hline $\begin{array}{l}\text { Fixed O\&M cost } \\
(\mathrm{R} / \mathrm{kW}) \text { per } \\
\text { year }\end{array}$ & 537 & 555 & 573 & 208 \\
\hline $\begin{array}{l}\text { Variable O\&M } \\
\text { cost }(\mathrm{R} / \mathrm{MWh})\end{array}$ & 0 & 0 & 0 & 0 \\
\hline $\begin{array}{l}\text { Variable fuel } \\
\text { cost (R/GJ) }\end{array}$ & 0 & 0 & 0 & 0 \\
\hline $\begin{array}{l}\mathrm{CO}_{2} \text { emissions } \\
(\mathrm{kg} / \mathrm{MWh})\end{array}$ & 0 & 0 & 0 & 0 \\
\hline
\end{tabular}

Table 25: Technologies for renewable sources - 2 [37]. 


\section{J. Import hydro [37]}

Appendix J displays the new technology costs input that were used in the model for technologies that use hydro imports as a source of energy. The contents of this appendix were taken from the IRP update report [37].

\begin{tabular}{|c|c|c|c|c|c|c|}
\hline & $\begin{array}{l}\text { Import } \\
\text { hydro } \\
\text { (Moz A) }\end{array}$ & $\begin{array}{l}\text { Import } \\
\text { hydro } \\
\text { (Moz B) }\end{array}$ & $\begin{array}{l}\text { Import } \\
\text { hydro } \\
(\text { Moz C) }\end{array}$ & $\begin{array}{l}\text { Import } \\
\text { hydro } \\
\text { (Zam A) }\end{array}$ & $\begin{array}{l}\text { Import } \\
\text { hydro } \\
\text { (Zam B) }\end{array}$ & $\begin{array}{l}\text { Import } \\
\text { hydro } \\
\text { (Zam C) }\end{array}$ \\
\hline $\begin{array}{l}\text { Rated capacity, } \\
\text { net (MW) }\end{array}$ & 1500 & 850 & 160 & 120 & 250 & 120 \\
\hline $\begin{array}{l}\text { Adjusted } \\
\text { overnight } \\
\text { capital cost } \\
(\mathrm{R} / \mathrm{kW})\end{array}$ & 21117 & 9874 & 17414 & 10877 & 7355 & 4900 \\
\hline $\begin{array}{l}\text { Fixed O\&M } \\
\text { cost }(\mathrm{R} / \mathrm{kW}) \\
\text { per year }\end{array}$ & 344 & 80.2 & 80.2 & 80.2 & 80.2 & 80.2 \\
\hline $\begin{array}{l}\text { Variable O\&M } \\
\text { cost }(\mathrm{R} / \mathrm{MWh})\end{array}$ & 0 & 0 & 13.9 & 13.9 & 13.9 & 13.9 \\
\hline $\begin{array}{l}\text { Variable fuel } \\
\text { cost (R/GJ) }\end{array}$ & 0 & 0 & 0 & 0 & 0 & 0 \\
\hline $\begin{array}{l}\mathrm{CO}_{2} \text { emissions } \\
(\mathrm{kg} / \mathrm{MWh})\end{array}$ & 0 & 0 & 0 & 0 & 0 & 0 \\
\hline
\end{tabular}

Table 26: Import hydro [37].

Where:

- Moz is Mozambique

- Zam is Zambia 


\section{K. Load shedding days and stages}

Appendix K shows the dates when the South African public electricity utility implemented load shedding, within 1 April 2018 to 31 March 2019 financial year. The stages are the highest load shedding stages implemented on that particular day. That is if the load shedding started at stage 1 , then increased to stage 2 and ended in stage 3 , stage 3 will be used for that day.

\begin{tabular}{|c|c|c|}
\hline Date & $\begin{array}{l}\text { Highest load shedding } \\
\text { stage implemented }\end{array}$ & Source \\
\hline $14 / 6 / 2018$ & stage 1 & [17] \\
\hline $15 / 6 / 2018$ & stage 1 & [17] \\
\hline $16 / 6 / 2018$ & stage 1 & {$[17]$} \\
\hline $31 / 7 / 2018$ & stage 1 & {$[17]$} \\
\hline $18 / 11 / 2018$ & stage 1 & {$[45]$} \\
\hline $1 / 12 / 2018$ & stage 2 & [24] \\
\hline $2 / 12 / 2018$ & stage 2 & [11] \\
\hline $3 / 12 / 2018$ & stage 2 & [25] \\
\hline $4 / 12 / 2018$ & stage 2 & [46] \\
\hline $5 / 12 / 2018$ & stage 2 & {$[47]$} \\
\hline $6 / 12 / 2018$ & stage 2 & [48] \\
\hline $7 / 12 / 2018$ & stage 2 & [49] \\
\hline $8 / 12 / 2018$ & stage 1 & [26] \\
\hline $10 / 2 / 2019$ & stage 2 & [20] \\
\hline $11 / 2 / 2019$ & stage 4 & [31] \\
\hline $12 / 2 / 2019$ & stage 3 & [30] \\
\hline $13 / 2 / 2019$ & stage 3 & [50] \\
\hline $14 / 2 / 2019$ & stage 2 & [21] \\
\hline $15 / 3 / 2019$ & stage 2 & [18] \\
\hline $16 / 3 / 2019$ & stage 4 & [51] \\
\hline $17 / 3 / 2019$ & stage 4 & {$[52]$} \\
\hline $18 / 3 / 2019$ & stage 4 & [56] \\
\hline $19 / 3 / 2019$ & stage 4 & {$[57]$} \\
\hline $20 / 3 / 2019$ & stage 4 & [53] \\
\hline $21 / 3 / 2019$ & stage 4 & [58] \\
\hline $22 / 3 / 2019$ & stage 2 & [54] \\
\hline $23 / 3 / 2019$ & stage 2 & [58] \\
\hline
\end{tabular}

Table 27: Load shedding days and stages. 